\title{
Uncertainties and validation of alien species catalogues: The Mediterranean as an example
}

\author{
Argyro Zenetos ${ }^{\text {a, }}{ }^{\star}$, Melih Ertan Çinar ${ }^{\mathrm{b}}$, Fabio Crocetta ${ }^{\mathrm{a}}$, Dani Golani ${ }^{\mathrm{c}}$, \\ Antonietta Rosso ${ }^{\text {d, e }}$, Gianna Servello ${ }^{f}$, Noa Shenkar ${ }^{\mathrm{g}, \mathrm{h}}$, Xavier Turon ${ }^{\mathrm{i}}$, Marc Verlaque ${ }^{\mathrm{j}}$ \\ ${ }^{a}$ Hellenic Centre for Marine Research, Institute of Marine Biological Resources and Inland Waters, GR-19013 Anavyssos, Greece \\ ${ }^{\mathrm{b}}$ Ege University, Faculty of Fisheries, Department of Hydrobiology, 35100 Bornova, Izmir, Turkey \\ ${ }^{c}$ The Hebrew University of Jerusalem, Department of Ecology, Evolution and Behavior, 91904 Jerusalem, Israel \\ ${ }^{\mathrm{d}}$ University of Catania, Department of Biological, Geological and Environmental Sciences, Earth Sciences Section, Corso Italia 57, I-95129 Catania, Italy \\ ${ }^{\text {e }}$ CoNISMa, Consorzio Nazionale Interuniversitario per le Scienze del Mare, Piazzale Flaminio, 9, I-00196 Rome, Italy \\ ${ }^{\mathrm{f}}$ University of Bologna, CdL Acquacoltura e Igiene delle Produzioni Ittiche, via A. Doria, 5 a/b, I-47042 Cesenatico (Forlì-Cesena), Italy \\ g George S. Wise Faculty of Life Science, Department of Zoology, Tel-Aviv University, Israel \\ ${ }^{\mathrm{h}}$ The Steinhardt Museum of Natural History Israel National Center for Biodiversity Studies, 69978 Tel Aviv, Israel \\ ${ }^{i}$ Center for Advanced Studies of Blanes (CEAB, CSIC), Department of Marine Ecology, Acces a la Cala S. Francesc 14, 17300 Blanes (Girona), Spain \\ j Aix-Marseille University and Toulon University, Mediterranean Institute of Oceanography (MIO), CNRS/INSU, IRD, UM 110, Campus of Luminy, 13288 \\ Marseille Cedex 9, France
}

\section{Keywords:}

Alien species

Taxonomists

Mediterranean

Check list

\section{a b s t r a c t}

The meticulous revision by taxonomic experts of established alien species in the Mediterranean resulted in a major revision of the list proposed by Galil et al. (2016), with 73 species to be excluded (35 species categorised as non-established and 37 as not true aliens), and 72 species added to the list. Consequently, by year 2016 the total number of established alien species in the Mediterranean reached 613, which is a $28 \%$ increase over the preceding four years. If we also consider casual species (208 species), the total number of alien species in the Mediterranean is 821. This is attributed to: new findings, change in establishment status of species previously known on the basis of few and scattered records, and results of phylogenetic studies in some cosmopolitan species. However, the true number of alien species reported here is considered to be an underestimation, as it does not include phytoplanktonic organisms, Foraminifera, cryptogenic and species known on the basis of questionable records that might turn out to be true aliens. EASIN and INVASIVESNET can play a major role in the future revision/update of the present list, which currently serves for assessing indicators that are necessary for policy, and for management of alien species in the Mediterranean Sea. An increasing trend in new arrivals since 1950, which culminated in the 2001 e2010 period, appeared to decline after 2010. Whether this negative trend is an indication of improvement, or is an artefact, remains to be seen. The current list provides a reliable updated database from which to continue monitoring the arrival and spread of invasive species in the Mediterranean, as well as to provide counsel to governmental agencies with respect to management and control. Current geographical, taxonomical and impact data gaps can be reduced only by instituting harmonised standards and methodologies for monitoring alien populations in all countries bordering the Mediterranean Sea.

\section{Contents}

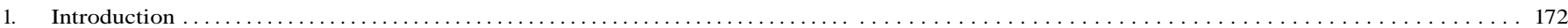

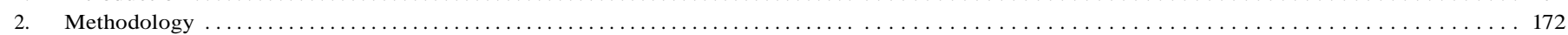

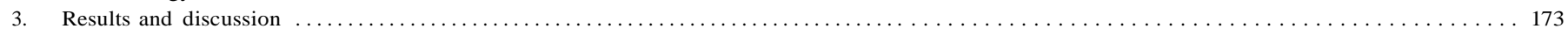




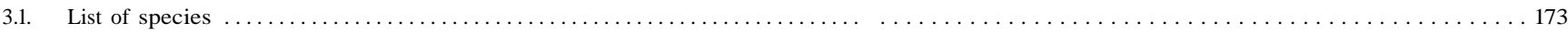

3.1.1. Species that should be excluded (misidentifications, unconfirmed, cryptogenic or non-established species) ........... 173

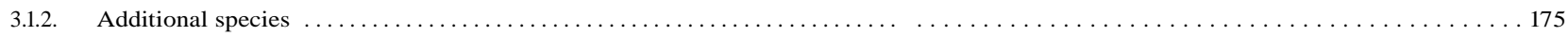

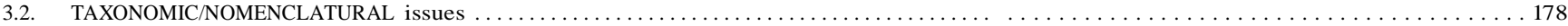

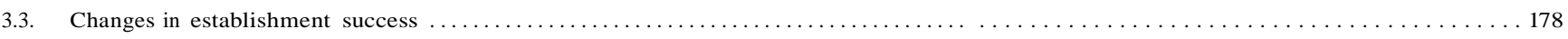

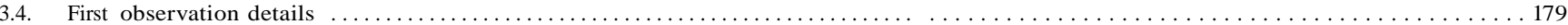

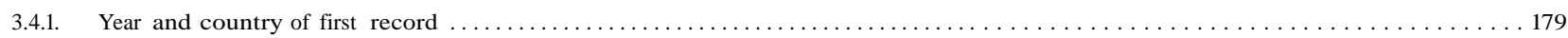

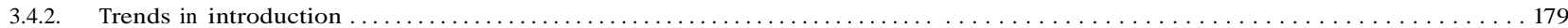

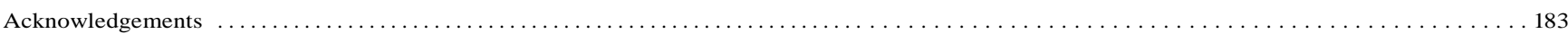

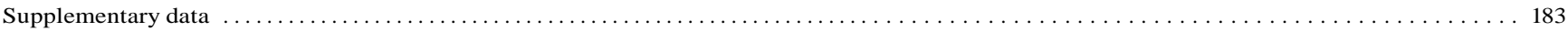

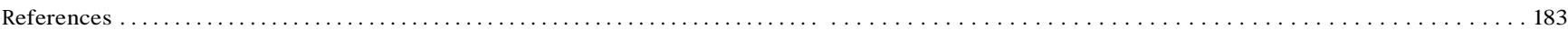

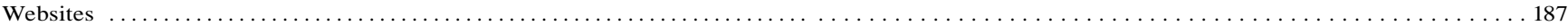

\section{Introduction}

Preparation of alien species (AS) checklists at larger scale and the development of relevant Web databases have been challenging tasks over the latest decades, with many funds and efforts being channeled in this direction from within the European Union (AquaNIS, DAISIE, EASIN, ESENIAS, NOBANIS). One major drawback in most of the aforementioned systems is the lack of long-term funding, which often results in a lack of updates which is, in turn, a prerequisite for delivering timely reliable information to environmental managers (Lucy et al., 2016). Nevertheless, the most serious problem is often the lack of expertise that ought to be engaged in such an endeavour. Species records in the existing data systems are often taken at face value without investigating their validity.

We acknowledge that no list at the national/regional scale is fully reliable unless it is the result of close collaboration of local experts. For instance, a list of AS in Greek waters that was first compiled in 2005 (Pancucci-Papadopoulou et al., 2005), and then was updated in 2009 (Zenetos et al., 2009) and again in 2010 (Zenetos et al., 2011b), is today out of date and includes some inevitable errors. For molluscs alone, out of about 100 potential alien taxa that were examined, almost half of the records turned out to be based on misidentifications or incorrect distributional data (FC, AZ unpublished data). This phenomenon is accentuated when no experts are involved, or where checklists are only based on knowledge that is provided by scientists with broad taxonomic expertise.

Apart from the aforementioned species-specific knowledge, any checklist also requires continuous updating in the light of new information on: a) new arrivals or overlooked species, e.g. Bugula neritina (Linnaeus, 1758); b) range expansion of already known species resulting in change of their establishment success, e.g. the brown shrimp Penaeus aztecus Ives, 1891, which within six years invaded almost the entire Mediterranean since the first record from Turkey (Deval et al., 2010), and whose status was switched from casual to invasive; c)changes in identification/nomenclature resulting from both traditional and molecular studies, e.g. the wellestablished and exploited prawn previously identified as Penaeus japonicus Spence Bate, 1888, and known in the Eastern Mediterranean since 1924 (Egypt: Balss, 1927), turned out to be Penaeus pulchricaudatus Stebbing, 1914 (Tsoi et al., 2014). Moreover, some alien fish species that are well-established in the Mediterranean and widely reported in the past literature with specific binomial names turned out to be species that are novel to science: Etrumeus teres (DeKay, 1842) vs Etrumeus golanii DiBattista et al., 2012; Saurida undosquamis (Richardson, 1848) vs Saurida lessepsianus Russell et al., 2015; Sillago sihama (Forsskål, 1775) vs Sillago suezensis Golani et al., 2014 (see DiBattista et al., 2012; Russell et al., 2015; Golani et al., 2016); d) changes in alien or native status for cryptogenic species resulting from genetic and biogeographical studies, e.g. the alga Caulacanthus okamurae Yamada (see Verlaque et al., 2015), the polychaete Chaetozone corona Berkeley and Berkeley, 1941 (see Le Garrec et al., 2017); e) changes in the introduction pathway resulting in the alteration of native/alien/cryptogenic status, e.g. the case of Aplysia dactylomela Rang, 1828, initially assumed to be ship transferred or unaided via Gibraltar (Scuderi and Russo, 2005), subsequently moved to the Lessepsian immigrant category (entering via the Suez Canal: Crocetta and Galil, 2012), and was lately transferred to unknown category (Valdes et al., 2013).

Despite the aforementioned problems, several AS lists have been published in the past from the Mediterranean Sea as a whole, among which Galil (2008, 2009), Nunes et al. (2014), and Zenetos et al. $(2005,2008 ; 2010 ; 2012)$ are noteworthy. Galil et al. (2016) recently published an expansive article based on a critical review of historical data, highlighting how the global trend of increasing numbers of AS is magnified in the Mediterranean. Based on these data, realistic and practicable priority actions are proposed in order to reduce potential impediments that hinder the implementation of a mitigation programme of the biological invasions. This same work emphasises the need for accurate lists of AS and the urgency of reducing current geographical and taxonomical data gaps. However, the dataset that accompanies that work suffers itself from all of these problems, which can only be resolved with the assistance of active participation of taxonomic experts. The aim of the present work is to present an updated list of established AS in the Mediterranean, and to stress the need for collaboration with locals and the contribution of taxonomic experts to compile accurate lists of AS, which are a prerequisite for any mitigation action.

\section{Methodology}

As is well known to taxonomists and conservation biologists, taxonomic knowledge has widely increased in the last two to three decades due to the even wider use of combined approaches, and some species reported in the past literature (usually from 1700 to around 1980) have never actually lived in the area where they have been widely recorded in the past. Using as a starting point the most recent list of AS (that of Galil et al., 2016), we performed a critical update based on reviews by Mediterranean taxonomists on macroalgae, Mollusca, Polychaeta, Ascidiacea, Bryozoa and Fishes. An extensive literature survey constitutes the base of the present article. Published records of AS were sought in both indexed and non-indexed journals, as well as in the gray literature, since most of the historical journals are non-indexed and, particularly, faunal records are still being published in non-indexed journals, thus allowing only manual searching. Nomenclature of species, first record and establishment success were all checked by local experts. 
The updates of the present work are as follows:

List of species. Some species that are listed are not alien and others have been excluded as they fall within one of the following criteria: i) species with unresolved taxonomic status (species complex or morphologically similar taxa) which may include native species; ii) records lacking proper scientific documentation; iii) cryptogenic species sensu Carlton (1996); iv) non-living records (i.e. loose valves, empty shells) unless known from the invaded area from a wide number of records/material; v) non-established spe- cies (AS, whose populations are known to be extinct or possibly not yet established, if the record is recent, i.e. within the past decade).

Taxonomic/nomenclatural issues. All species names were checked following the World Register of Marine Species (WoRMS Editorial Board, 2016). Discrepancies were reported to the WoRMS editors.

Establishment success. The terminology used varies among in- vasion biologists. For species reported once or twice on the basis of single individuals, we retain the term 'casual'. If there are many records, spread over time and place, it is assumed that the species are established, even though there may be no evidence of reproduction.

Year and country of the first record. For unpublished data, we searched museum collections and contacted the authors of the first report when possible. Dates of personal observations were also considered. We refer to the first recipient country according to the first collection/observation date, not according to reporting date.

Trends in introduction of new AS. We used the compiled data to ascertain the rate of new introductions, presented as a yearly rate (average per decade) since 1950. For the last six years (2011e2016) of the analysis, the number of recorded species is an underestimate. This is due to the time lag between the sampling of the species and the publication of the data, which can take several years. To better demonstrate the introduction rate, we also used the collection dates of non-established species (casual records) which have been reported after 1950 .

\section{Results and discussion}

\subsection{List of species}

Our updated list of established aliens in the Mediterranean, includes species that i) are not included in the lists published by Galil (2008, 2009), Zenetos et al. (2010, 2012), Nunes et al. (2014), Galil et al. (2016); ii) were reported after these inventories, and iii) species first recorded a long time ago, which were formerly considered native and whose alien status has been recently proven in the body of literature.

Seventy four of the reported species should be excluded, 37 as not true aliens, 36 as not established. Another 72 established species are added to the list of Galil et al. (2016). These are: macroalgae (16 species), Mollusca (3), Polychaeta (28), Crustacea (4), Bryozoa (4), Ascidiacea (9), Cnidaria (3), Turbellaria (1); Sipuncula (1), and fishes (3). The total number of established AS in the Mediterranean is 613 .

\subsubsection{Species that should be excluded (misidentifications,} unconfirmed, cryptogenic or non-established species)

According to the exclusion criteria of Galil et al. (2016), 37 species (6 macroalgae, 19 Mollusca, 7 Polychaeta, 1 Crustacea, 1 Bryozoa, 1 Cnidaria) which were reported as established should be removed from the Mediterranean aliens list of established species, either because their identification has been revised or because they are cryptogenic or questionable or based on empty shells (molluscan species). A further 36 species (9 macroalgae, 14 Mollusca, 2 Polychaeta, 3 Crustacea, 1 Ascidiacea, 1 Echinodermata, 7
Fish), should be removed from the list as the reports on them are based on casual records. We provide here a detailed explanation for each taxonomic/ecofunctional group. For each group we provide in brackets the number of the species that should be removed as not true aliens and the number of species whose reports are based on casual reports.

3.1.1.1. Macroalgae (6 p 9). Five species namely Antithamnionella boergesenii (Cormaci \& G.Furnari) Athanasiadis, Antithamnionella elegans (Berthold) J.H.Price \& D.M.John, Antithamnionella spirographidis (Schiffner) E.M.Wollaston, A. ternifolia (J.D.Hooker \& Harvey) Lyle and Caulerpa chemnitzia (Esper) J.V.Lamouroux are classified as debatable (cryptogenic) in Verlaque et al. (2015) and as such should be provisionally removed from the aliens' list of the Mediterranean Sea. Chondria collinsiana M.A.Howe, is a probable misidentification of Chondria curvilineata F.S. Collins \& Hervey.

Acrochaetium robustum Børgesen, A. spathoglossi Børgesen, A. subseriatum Børgesen, Ascophyllum nodosum (Linnaeus) Le Jolis, Derbesia boergesenii (Iyengar \& Ramanathan) Mayhoub, Fucus spiralis Linnaeus, Grateloupia patens (Okamura) S.Kawaguchi \& H.W.Wang, Hypnea flagelliformis Greville ex J.Agardh, and Rhodymenia erythraea Zanardini, which are only known from the original records (see Verlaque et al., 2015), must also be excluded from the list.

3.1.1.2. Mollusca (19 p 14). Records of Alectryonella crenulifera (Sowerby G.B. II, 1871) and Alectryonella plicatula (Gmelin, 1791) by Mienis et al. (2012a, b) were contemporarily confuted by Crocetta et al. (2015a) and Huber (2015). Based on molecular analysis of Mediterranean specimens, Crocetta et al. (2015a) suggested that both species belong to Dendostrea cf. folium (Linnaeus, 1758) while, based on shell morphology, Huber (2015) suggested that they belong to Dendostrea rosacea (Deshayes, 1836). Mediterranean specimens originally ascribed to Murchisonella columna (Hedley, 1907) were recently described as Murchisonella mediterranea Peñas and Rolan, 2013, a Mediterranean endemic species (see Perras and Rolan, 2013). The record of Cantharus tranquebaricus (Gmelin, 1791) was based on three empty shells from the Mediterranean coasts of Israel (Mienis, 2003). However, this record was subsequently amended by the same author (Mienis, 2006), who stated that the record was presumably based on three mislabelled specimens from India, and that the species should have been excluded from AS lists. The presence of Spondylus groschi Lamprell and Kilburn, 1995 and Spondylus multisetosus Reeve, 1856 is disputed due to the confusion with their congeneric S. spinosus Schreibers, 1793 (Zenetos et al., 2004). Therefore, they are labelled as "questionable" species until their systematics is revised. The presence of Centrocardita akabana (Sturany, 1899) in the Mediterranean is dubious. Juvenile specimens of the eastern Atlantic-Mediterranean taxon Cardites antiquatus (Linnaeus, 1758) may be easily confused this alien taxon. Therefore, a DNA barcoding approach is required in order to support the presence of C. akabana in the Mediterranean. Dendrodoris fumata (Rüppell and Leuckart, 1830) was recorded from Israel (Barash and Danin, 1986), Turkey (Çevik et al., 2012) and Italy (Trainito and Doneddu, 2014). However, published identifications were never confirmed by molecular and/or anatomical data, and therefore remain all highly doubtful. The past presence of Zygochlamys patagonica (King, 1832) in the Mediterranean is now considered as very doubtful, as Mannino et al. (2016) have excluded the records from the Alboran Sea and Italy since it is not sure if all Mediterranean records were based on discards in the field of dead specimens imported with shrimps (some presumably even with soft parts), or if specimens obtained 'from fishermen' may refer to trawlings from the Atlantic by fleets based only in the Mediterranean Sea. 
In addition, although molluscan records based only on empty shells were included in Zenetos et al. (2004) and subsequent lists, in accordance with Marchini et al. (2015) they should be removed from all Mediterranean alien inventories, unless records are based on a wide number of specimens. In particular, we here refer to:

$\checkmark$ Antigona lamellaris Schumacher, 1817: based on a single shell from Turkey (Engl and Çeviker, 1999);

$\checkmark$ Canarium mutabile (Swainson, 1821): reported from Israel (Mienis, 2001) on the basis of three empty shells;

$\checkmark$ Cerithium litteratum (Born, 1778): only known by a single empty shell found in Greece in 1978 (Garilli and Vardala-Thedorou, 2005);

$\checkmark$ Cerithium nesioticum Pilsbry and Vanatta, 1906: only known from empty shells from Israel (Mienis, 1977) and Cyprus (Bogi et al., 1989);

$\checkmark$ Ergalatax contracta (Reeve, 1846): only known from empty shells (Mienis, 2004);

$\checkmark$ Haliotis rugosa pustulata Reeve, 1846: a few shells only in Israel and Libya (see Zenetos et al., 2004);

$\checkmark$ Monetaria annulus (Linnaeus, 1758): Mienis (2004) rejected earlier records in the Levantine basin. Records from the centralwestern Mediterranean are based on empty shells or unconfirmed records;

$\checkmark$ Notocochlis gualteriana (Recluz, 1844): only known from two empty shells (Mienis, 1986, 2000);

$\checkmark$ Rissoina ambigua (Gould, 1849): a microspecies, whose records are based on few empty shells found in Turkey in 2003 (Mienis, 2004);

$\checkmark$ Trapezium oblongum (Linnaeus, 1758): only known by a single valve (Mienis, 1980). Its real occurrence in the Mediterranean Sea was considered doubtful by Mienis (1980) himself.

Finally, the following species are not established (species recorded once or twice):

$\checkmark$ Acanthopleura sp.: few specimens from Tripoli (Lybia) and Zarzis (Tunisia), where the species is considered as casual (see Zaouali et al., 2007; Crocetta et al., 2014; Ounifi-Ben Amor et al., 2016);

$\checkmark$ Acar plicata (Dillwyn, 1817): only known from a single record in Israel (Barash and Danin, 1986), as the additional record from Greece should be considered as questionable (see Corsini-Foka et al., 2015);

$\checkmark$ Atactodea striata (Gmelin, 1791): only known from two single records - Barash and Danin (1977) and Cachia et al. (2004);

$\checkmark$ Conus fumigatus Hwass in Bruguiẻre, 1792: only recorded in 1974e1976 from a single locality in Libya (REckel, 1986), with no follow up;

$\checkmark$ Chiton hululensis (E. A. Smith, 1903): only known from two old single records, with no follow up (Barash and Danin, 1992);

$\checkmark$ Cuthona perca (Er. Marcus, 1958): only known from Italy on the basis of an old record of a single specimen (Perrone, 1995);

$\checkmark$ Halgerda willeyi Eliot, 1904: only known from Croatia on the basis of an old record of a single specimen (Turk, 2000);

$\checkmark$ Lodderia novemcarinata (Melvill, 1906): only known from 5

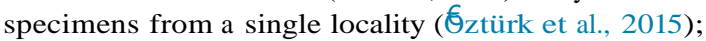

$\checkmark$ Mercenaria mercenaria (Linnaeus, 1758): the Northern quahog cannot be classified as abundant, and not even as established. Attempts were made to introduce the clam to the Etang de Thau (France), while the putative records from Italy were confuted early after Zenetos et al. (2004), followed by the first concrete record of few specimens (see Turolla, 2006). No populations have successfully been established anywhere in the Mediterranean; $\checkmark$ Pinctada margaritifera (Linnaeus, 1758): its potential introduction in Italy has been recently confuted (see discussions in Crocetta et al., 2009), so that it is only known on the basis of a single remaining record from Egypt (Zenetos et al., 2004);

$\checkmark$ Plocamopherus tilesii Bergh, 1877: only known from Turkey on the basis of a single specimen that was collected in 2009 (Yokeș et al., 2012);

$\checkmark$ Spondylus nicobaricus Schreibers, 1793: only known from Israel on the basis of an old record of a single specimen (Zenetos et al., 2004);

$\checkmark$ Stomatella impertusa (Burrow, 1815): known from a single record from Turkey (see Zenetos et al., 2004), and a possible, but still doubtful, record from Malta (see Arias et al., 2013b), where the species was not found again despite careful researches (FC, unpublished data);

$\checkmark$ Teredothyra dominicensis (Bartsch, 1921): specimens from Turkey were predominantly acquired from a shipwreck off the coast of Kas. The Greek record should not be considered, as a single specimen was found on a piece of driftwood that was recovered off the coast of Fourni Island (Luisa Borges, pers. Comm.). Following Marchini et al. (2015), the aforementioned records do not qualify for a successful establishment.

3.1.1.3. Polychaeta ( $7 \mathrm{p}$ 2). The following species must be omitted:

$\checkmark$ Eunice indica Kinberg, 1865: most probably it could be E. vittata (see discussion in Ben-Eliahu, 1976);

$\checkmark$ Hydroides dianthus (Verrill, 1873): according to a recent molecular study (Sun et al., 2017), the global invader H. dianthus seems to be originated from the Mediterranean Sea. However, it was emphasised that specimens of Hydroides cf. dianthus in the Black Sea could have been introduced to the region from the West Coast of the USA;

$\checkmark$ Linopherus incarunculata (Peters, 1854): this species has not been reported from the Mediterranean Sea. The only species reported was L. acarunculatus (Monro, 1937) that was later proved to be a misidentification of L. canariensis Langerhans, 1881 (see Çinar, 2009);

$\checkmark$ Marphysa disjuncta Hartman, 1961: the species was re-identified as Marphysa cinari Kurt-Sahin 2014, a Mediterranean endemic species (Kurt Sahin, 2014);

$\checkmark$ Neanthes willeyi (Day, 1934): Fauvel (1955) reported that N. willeyi was found in Port Said (as Nereis capensis), quoting his 1927 paper (Fauvel, 1927). Indeed Fauvel (1927) found this species at one station in the Suez Canal just $5 \mathrm{~km}$ away from Port Said. Ben-Eliahu (1991) considered this species as AS in the Mediterranean, based on the expression made by Fauvel (1955). As there is no true record of this species in the Mediterranean, this species should be excluded from the list;

$\checkmark$ Onuphis eremita oculata Hartman, 1951: the record was reidentified as Onuphis eremita Audouin and Milne Edwards, 1833. Arias and Paxton (2014) stated 'Since the original description of $\mathrm{O}$. eremita indicates the presence of eyespots, as well as that they are present in the neotype in most of the studied specimen, it is very likely that the subspecies reported by Çinar (2009) is actually O. eremita and hence is a Mediterranean native species';

$\checkmark$ Laonome elegans Gravier, 1906: it is a questionable species (see Ben-Eliahu, 1972, p. 232)

In addition, the following species are not established (species recorded once or twice): 
$\checkmark$ Perinereis nuntia (Lamarck, 1818): the species was regarded as casual (Zenetos et al., 2010) as it was only reported from Port Said (Egypt) in 1924 by Fauvel (1927). There is no subsequent record of this species in the Mediterranean;

$\checkmark$ Branchiomma boholense (Grube, 1878): besides the record by Knight-Jones et al. (1991), all other reports are questionable. The reports from the western Mediterranean were proved to be B. bairdi (McIntosh, 1885) (see Çinar, 2009; Giangrande et al., 2012), as well as the reports from Cyprus (see Çinar, 2005).

\subsubsection{Crustacea (1 $\mathrm{p}$ 3). The following species must be omitted:}

$\checkmark$ Nothobomolochus fradei Marquès, 1965: reported as parasite on Herklotsichthys punctatus (Rüppell, 1837), which was caught in Egyptian waters off the Alexandrian coast in 2008 (El-Rashidy and Boxshall, 2009, 2010). It cannot be confirmed as an alien because of its natural distribution [which includes both the Arabian Gulf and the Eastern Atlantic coast (Gulf of Guinea)]. This widespread distribution indicates that it could be native in the Mediterranean, where it was also found on the native fish Sardina pilchardus (Walbaum, 1792) (G. Boxshall, pers. comm.);

$\checkmark$ Bemlos leptocheirus (Walker, 1909): only known from a single record from Port Said (Schellenberg, 1928);

$\checkmark$ Eriocheir sinensis H. Milne Edwards, 1853: based on four records, of single specimens in lagoons, 46 years apart, one in France (1959: Petit, 1960) and three in Italy $(2005,2013,2014$ : see Bettoso and Comisso, 2015);

$\checkmark$ Grapsus granulosus H. Milne Edwards, 1853: it is not established in Tunisia or other Mediterranean localities (Ounifi-Ben Amor et al., 2016).

3.1.1.5. Ascidiacea (0 p 1). Perophora multiclathrata (Sluiter, 1904): reported in Corsica (Monniot, 1983; Monniot and Monniot, 1987). It is different from Perophora viridis Verrill, 1871. Common synonyms are Perophora bermudensis Berrill, 1932 and Perophora formosana (Oka, 1931) (Monniot and Monniot, 1987; Kott, 1985). If we accept these synonymies, then P. multiclathrata occurs in the Indo-Pacific, and on both sides of the tropical Atlantic. The Mediterranean reports, however, concern only two findings in the same locality (F. Monniot, pers. comm.), thus the species cannot be considered as presently established.

3.1.1.6. Bryozoa (1 $\mathrm{b}$ 0). Schizoretepora hassi Harmelin, Bitar \& Zibrowius, 2007: Harmelin et al. (2016) considered this species as cryptogenic.

3.1.1.7. Echinodermata ( 0 p 1). Ophiocoma scolopendrina (Lamarck, 1816): record based on a single specimen (Zaouali et al., 2007).

3.1.1.8. Cnidaria/Anthozoa ( $1 \mathrm{p}$ 0). The colonial scleractinian Oculina patagonica de Angelis, 1908, was described from fossil material in South America. It is assumed to have been introduced in anthropogenic times into the Mediterranean, but as "nothing is known on the actual range of the species" (Zibrowius, 1974). However, genetic, historic, demographic, and fossil evidence suggests that $\mathrm{O}$. patagonica has not been anthropogenically introduced into the Mediterranean from the western North Atlantic. Mediterranean and Atlantic populations are genetically distinct and appear to have begun diverging about 5 Mya (Leydet and Hellberg, 2015). Results support the hypothesis that Oculina has had a long history in the eastern Atlantic, but remained undetected until it recently began expanding to invasive numbers in the Mediterranean, likely in response to environmental changes (Leydet and Hellberg, 2015).
3.1.1.9. Fish ( 0 p 7). Seven species must be omitted as not established:

$\checkmark$ Sciaenops ocellatus (Linnaeus, 1766): aquaculture escapee. Only two specimens have been collected to date. This species does not reproduce in the wild in the Mediterranean (Golani et al., 2015);

$\checkmark$ Chanos chanos (Forsskål, 1775): only one record from Turkey (Evzarol and G€koylu, 2012);

$\checkmark$ Coryogalops ocheticus (Norman, 1927): only one record from Egypt (Golani et al., 2016);

$\checkmark$ Elates ransonnettii (Steindachner, 1876): only 2 single records, five years apart, one from Italy in 2005 (Mastrototaro et al., 2007) and one from Croatia in 2010 (Dul cic et al., 2010);

$\checkmark$ Pampus argenteus (Euphrasen, 1788): a museum record in Croatia in 1896), followed by a record in Tunisia in 2007 (Sami et al., 2014) with no follow up, cannot account for establishment of the species;

$\checkmark$ Tridentiger trigonocephalus (Gill, 1859): only one specimen has been collected. However, the people that collected the specimen claimed that they saw several specimens in the same location that looked similar to this species (DG, unpublished). With the lack of concrete evidence, the species is classified as nonestablished;

$\checkmark$ Abudefduf vaigiensis (Quoy and Gaimard, 1825): the species that occurs in the Levant is Abudefduf saxatilis (see: Tsadok et al., 2015), therefore, it obviously did not arrive via the Suez Canal and it is not rare. However, recently Vella et al. (2016) claim that in their genetic study they found that both A. vaigiensis and A. saxatilis co-exist in Malta.

\subsubsection{Additional species}

Annex 1 includes 72 established aliens in the Mediterranean that are missing in Galil et al. (2016). Among the taxa, most of the macroalgae are included in the recent CIESM atlas (Verlaque et al., 2015), while 4 species, namely Monosporus indicus Børgesen, Dictyota cyanoloma Tronholm, De Clerck, Gomez Garreta \& Rull Lluch, Cutleria multifida (Turner) Greville and Halimeda incrassata (J. Ellis) J. V. Lamouroux were reported in 2016 (Hoffman and Wynne, 2016; Aragay et al., 2016; Kawai et al., 2016; Alos et al., 2016). Previously considered as debatable (Verlaque et al., 2015), the introduction of the Red Sea species Palisada mariserubri (K.W. Nam \& Saito) K.W. $\mathrm{Nam}$ in the Mediterranean has been confirmed by reports from Greece (Tsiamis et al., 2015) and Tunisia (Boudouresque et al., 2016).

The molluscan aliens are adequately covered. Exceptions are: i) Indothais sacellum (Gmelin, 1791), a species first recorded in 2000 as very common in the Beyrouth Harbour, Lebanon (Zibrowius and Bitar, 2003). The species is also spreading in other Mediterranean countries, such as Israel, where it was found in at least in two localities (Mienis, 2006); ii) Fossarus eutorniscus Melvill, 1918, a taxon that was first reported in the Mediterranean Sea as Parviturbo dibellai Buzzurro and Cecalupo, 2006 on the basis of a wide number of shells from Israel and Turkey (Buzzurro and Cecalupo, 2006), and subsequently assigned to the Lessepsian species F. eutorniscus (Rubio et al., 2015). In addition, Galil et al. (2016) excluded "species with unresolved taxonomic status (species complex or morphologically similar taxa)". This approach presumably led to the exclusion of Dendostrea cf. folium from the species list, although this taxon is clearly an AS in the Mediterranean Sea and only its specific attribution is problematic due to the absence of molecular studies that aim to solve the Indo-Pacific Dendostrea complex of species (Crocetta et al., 2015a).

The majority of polychaetes are included in the reviews by Zenetos et al. (2010, 2012) and Çinar (2013). The most recently 
introduced species is Diopatra marocensis Paxton, Fadlaoui \& Lechapt, 1995, which was reported from different localities along the Levant and Aegean coasts of Turkey (Çinar et al., 2014a) and might have been introduced to the area via the ballast water of ships. Furthermore, worth mentioning are:

$\checkmark$ Prionospio pulchra Imajima 1990: first reported from the Greek coast of the Aegean Sea by Pancucci-Papadopoulou et al. (2005) and subsequently reported from Levantine, Sea of Marmara and Black Sea coasts by Dagli and Çinar (2011). However, the specimens that were collected on the Italian coast of the Tyrrhenian Sea in 1982 and identified as P. cirrifera Wiren, 1883 by Giangrande and Gambi (1982) were re-identified as P. pulchra (Dagli and Çinar, 2011);

$\checkmark$ Timarete punctata (Grube, 1859), which was possibly confused with T. semicincta (Ehlers, 1905) identified from the Lebanon coast in 1965 (Laubier, 1966), occurred abundantly in harbour environments on the southern coast of Turkey (Çinar, 2007);

$\checkmark$ Chaetozone corona Berkeley and Berkeley, 1941: the species was initially reported as cryptogenic in the Mediterranean Sea (Çinar and Ergen, 2007), but it was later reported from the eastern Atlantic coast as an AS that was introduced by shipping from the East Coast of the USA (Le Garrec et al., 2017). Therefore, the species can be also considered as an established alien species in the Mediterranean Sea;

$\checkmark$ Loimia medusa (Savigny, 1818) was mentioned as questionable in Zenetos et al. (2010). However, there is growing evidence that this species occurs in the eastern Mediterranean and can be regarded as an established AS (Dorgham and Hamdy, 2015; MEÇ pers. observ.). The first record of this species was given by Rullier (1963) in the Sea of Marmara. In the Mediterranean basin, L. medusa was included in species lists from Greece (collection date: 1976) (Bogdanos and Satsmadjis, 1983) and Italy (collection date: 1987) (Albertelli et al., 1995);

$\checkmark$ Eurythoe complanata (Pallas, 1766): whose first report from the Mediterranean Sea (Israeli coast) was given by Monro (1937). The species was subsequently reported from different parts of the Mediterranean Sea, including Gibraltar (see Arias et al., 2013a). As Çinar (2008) postulated, unless the taxonomic status of the Eurythoe species, E. syriaca Kinberg, 1857 and E. hedenborgi Kinberg, 1857, which were originally described from the eastern Mediterranean by Kinberg (1857) and subsequently considered as a junior synonyms of E. complanata or indeterminable by different authors, are solved, it is hard to determine the status and first arrival time of E. complanata in the Mediterranean Sea. However, as types of E. syriaca and E. hedenborgi are presumably lost and their original descriptions were too short and without figures, we should assume, for the time being, that the taxonomic status of these species are nomen dubium. Therefore, we can conclude that E. complanata occurs in the region and is an established alien species;

$\checkmark$ Eurythoe laevisetis Fauvel, 1914 was first reported from the Chafarinas Island (Alboran Sea) and Malta in the Mediterranean Sea, and was considered as an established alien species (Arias et al., 2013a). However, as this species was originally described from the eastern Atlantic (Gulf of Guinea) and known also from the Canary Island (Arias et al., 2013a), this species might have entered into the Mediterranean by the process of range expansion rather than by human assistance. However, there is a gap in the distribution of the species within the Mediterranean, which is absent in the westernmost part. Therefore, this species should be kept in the list as an established alien species until more data about its distributional pattern in the western Mediterranean are accumulated that would enable us to realise the pathway through which it has become established in Maltese waters; natural dispersal via Gibraltar or shipping?

Crustacea are also successfully covered. In addition to the two Cumacean species Eocuma rosae Corbera and Galil, 2007 and Eocuma sarsii (Kossmann), 1880 that are reported as established in Corbera and Galil (2016), the copepod Parvocalanus crassirostris (Dahl F., 1894), an old record from Egypt (Gurney, 1927), which was recently found in the Adriatic (Vidjak et al., 2016) is missing. The amphipod Linguimaera caesaris Krapp-Schickel, 2003 has been mistakenly deleted from earlier lists and reported as Hamimaera hamigera (Haswell, 1879) (Zenetos et al., 2011a).

With regards to alien ascidians the list is enriched with the addition of nine species:

$\checkmark$ Aplidium accarense (Millar, 1953): recently found in Spain and Italy, and is likely introduced by vessels (Lopez-Legentil et al., 2015);

$\checkmark$ Ascidiella aspersa (Müller, 1776): described from Norway A. aspersa is a widespread species that is introduced into many parts of the world. It can be safely assigned an introduced status in the Mediterranean (Nishikawa et al., 2014; Lopez-Legentil et al., 2015). Its vector is most likely vessels, as the species occurs in harbours. The oldest Mediterranean report is that of Delle Chiaje (1828) (as Phallusia mamillaris, according to Traustedt, 1883) from the Gulf of Naples;

$\checkmark$ Botrylloides nigrum (Herdman, 1886): reported by Perēs 1958 from the coast of Israel (see also Sheets et al., 2016 for a recent report in Israel);

$\checkmark$ Ciona robusta Hoshino and Tokioka, 1967: the cosmopolitan taxon Ciona intestinalis has been recently shown to comprise several cryptic species, of which the most widespread are the so-called Ciona intestinalis type A and type B (Zhan et al., 2010). Recent studies (Brunetti et al., 2015; Pennati et al., 2015) have shown that Ciona intestinalis type A is in fact C. robusta. Genetic data (Bouchemousse et al., 2016) support the introduced status of C. robusta in Europe, based on low genetic diversity as compared with the presumed native area in the NW Pacific. Nowadays, C. robusta can be safely assigned an introduced status in the Mediterranean, being reported there since the 19th Century (Savigny, 1816; as Phallusia intestinalis), most often under the name C. intestinalis;

$\checkmark$ Clavelina oblonga Herdman, 1880: this is a true introduced species that has been mistakenly described as a new species Clavelina phlegraea Salfi, 1929 in the Mediterranean and is found in Italy, Corsica, and Spain (Ordonez et al., 2016);

$\checkmark$ Diplosoma listerianum (Milne Edwards, 1841): often cited as cryptogenic, it can be considered as introduced in the Mediterranean. It is a species complex, but the Mediterranean clade is native to the Atlantic shores (Perez-Portela et al., 2013). Della Valle (1877) first reported this species (as Pseudodidemnum listerianum Milne-Edwards, 1841) from the Gulf of Naples;

$\checkmark$ Microcosmus anchylodeirus Traustedt, 1883: collected in Corsica over a period of at least 12 years (Monniot, 2016). The donor region and the introduction pathway of this western-Atlantic species are unknown;

$\checkmark$ Polyclinum constellatum Savigny, 1816: Halim and Abdel Messeih (2016) report this species from the area of Port Said;

$\checkmark$ Styela clava Herdman, 1881: although the first record in Egypt (Ghobashy and Abdel Messeih, 1991) is unsubstantiated (insufficient description), the species was reported from France (Davis and Davis, 2008; first seen in 2004), and now is spreading into the Mediterranean (Çinar, 2016).

Four Bryozoa species should be added. The vast majority of them 
were reported in Lebanon, after the inventories of Zenetos et al. (2005, 2012). To be more precise, Harmelin (2014) and Harmelin et al. (2016), based on collections made some years earlier, reported 27 AS from Lebanon. Among them, two are cryptogenic and others such as Thalamoporella rozieri (Audouin, 1826), and Celleporaria vermiformis (Waters, 1909) cannot be included in the present inventory because they were recorded from a single site. In contrast, other species seem to be widely distributed in the Levantine Sea as they have also been recorded along the coasts of Israel by Sokoloveret al. (2016).

$\checkmark$ Celleporina bitari Harmelin, 2014: this species has been recorded in samples that were collected in 2002 and 2003 in Lebanon. Also known from the Red Sea, C. bitari has been considered by Harmelin (2014) as introduced into the Mediterranean via Suez either through shipping or colonising successive relays along the Canal;

$\checkmark$ Celleporaria cf. sherryae Winston, 2005: this species has been reported from Lebanon by Harmelin (2014) and is considered as an alien bryozoan in the Mediterranean by Harmelin et al. (2016) who postulate its introduction through Gibraltar via long-distance vessels;

$\checkmark$ Microporella genisii (Audouin, 1826): this species has been reported from the coasts of Lebanon, predominantly in natural habitats on various substrata and in a wide depth range $(5 \mathrm{e} 40 \mathrm{~m})$;

$\checkmark$ Mucropetraliella thenardii (Audouin, 1826): this species has been reported from the coast of Lebanon (Harmelin, 2014; Harmelin et al., 2016) and from some localities along the coasts of Israel by Sokolover et al. (2016).

With regards Cnidaria, molecular analyses of the widely distributed jellyfish Aurelia, have revealed the presence of Aurelia coerulea von Lendenfeld, 1884 and Aurelia solida Browne, 1905, as established AS in the Mediterranean Sea (Scorrano et al., 2016). The firework anemone Pachycerianthus multiplicatus Carlgren, 1912 was reported from Iskenderun Bay based on material collected in 2009 and might have been introduced to the area by ballast waters of vessels (Çinar et al., 2014b).

The flatworm Maritigrella fuscopunctata (Prudhoe, 1978) was reported from Malta in 2015 but it was known from Israel and Lebanon since 2014 (Portelli et al. in Crocetta et al., 2015a,b).

The sipunculan Aspidosiphon elegans (Chamisso and Eysenhardt, 1821) that was reported by Wesenberg-Lund, 1957, appears to be established in the Levantine Sea (Turkey: Açik, 2011).

Finally in this revised list, three fish species are added:

$\checkmark$ Equulites elongatus (Günther, 1874): known from Israel since 2011, and is now established in the area (Golani, unpublished data);

$\checkmark$ Cryptocentrus caeruleopunctatus (Rüppell, 1830): reported in Israel by Rothman and Goren, 2015;

$\checkmark$ Stolephorus indicus (van Hasselt, 1823): reported in Israel by Fricke et al. (2015)

The information gaps, the lack of previous records, as well as difficulties in taxonomic identification and general confusion in species global biogeography and species level biodiversity makes it difficult for some groups to decide on categorising them as alien or cryptogenic. This is a common problem in alien marine species which will be only solved with molecular studies. Here are some examples of established species that are presently not included in our list as there is not enough information on taxonomic status, introduction vector, cryptic diversity, etc. These examples are best labelled as cryptogenic species until more information is available.
The ascidian Clavelina lepadiformis (Müller, 1776). Turon et al. (2003) show that the form living inside ports in the Mediterranean is likely introduced from the Atlantic. But, at present, although the forms living inside and outside of ports are considered as two clades of a single species, no formal taxonomic distinction has been made. The earliest record that specifically mentioned C. lepadiformis inside ports in the Mediterraenan is Della Valle (1877) in Naples, and the introduction vector is likely via vessels.

The ascidian Perophora viridis Verrill, 1871 is common in the West Atlantic Ocean, where it was described. The species is present also in the Pacific Ocean. In the Mediterranean P. viridis was signaled in 1921 by Neppi (under the synonym P. dellavallei) in Naples, then by Brunetti and Menin (1977) in Venice, and by Monniot and Monniot (1987) in Corsica. It is abundant in the Iberian Mediterranean (Turon, 1987; Ramos-Espla, 1988). Although it is sometimes labelled as alien, we consider P. viridis as cryptogenic. This species may be abundant in the Atlanto-Mediterranean area but has been confused with Perophora listeri Wiegman, 1835. Nowadays, although P. listeri and P viridis are accepted as different species, it is impossible to disentangle to which species old reports are referring to. It seems difficult to consider it to be introduced if it is abundant and widely distributed in non-artificial habitats.

The golden star tunicate Botryllus schlosseri (Pallas, 1766) is distributed worldwide and has a marked polymorphism in chromatic patterns and colony shapes. As in other widely distributed and polymorphic species, it has been recently shown that the taxon B. schlosseri is a complex of five genetically differentiated species (Lopez-Legentil et al., 2006; Bock et al., 2012), and all of them present in the Mediterranean. The most widespread of them is the so-called Clade A, which in turn is subject to ongoing speciation processes (Griggio et al., 2014). It is impossible, in retrospect, to assign previous reports of the species complex to any of its true genetic species. In addition, it is not clear which is the native area of the invasive Clade A (Lejeusne et al., 2011; Nydam et al., 2017; Reem et al., 2017). It is therefore advisable to leave the status of B.schlosseri in the Mediterranean as cryptogenic, for the time being.

The bryozoan Bugula neritina (Linnaeus, 1758) has belonged to the Mediterranean fauna for a very long time. Recent molecular data (Fehlauer-Ale et al., 2014) have shown that B. neritina is a complex of three cryptic species, but unfortunately Mediterranean populations were not considered in that study (Harmelin et al., 2016).

The bryozoan Scorpiodinipora costulata (Canu and Bassler, 1929). Considering the broad allopatric distribution of this morphotype across the oceans and the low capacity of dispersal of species with short-lived larvae, it is likely that this material includes several sibling species.

The bryozoan Microporella harmeri Hayward, 1988. It is reported from the coast of Lebanon (Harmelin et al., 2009; Harmelin et al., 2016) and Israel (Sokolover et al., 2016). The species is distributed from the Atlantic to the Red Sea and the Indian Ocean, with populations from the different areas showing a series of slightly different "morphs" for several characters. Therefore, although it is listed in Zenetos et al. (2012) and appears to be established, it is very difficult to say with certainty whether it belongs to a complex of cryptogenic species.

Abudefduf saxatilis (Linnaeus, 1758) is an Atlantic fish that is established in the Mediterraneanea Sea, but the pathway of its introduction remains debatable. The first record of this species in the Mediterranean is from the Gulf of Naples (Tardent, 1959) and the second record (as A. vaigiensis) is from the Levantine basin (Goren and Galil, 1998). These facts indicate that the species has increased its range from West to East, after penetration via Gibraltar. Yet, the situation concerning Abudefduf spp. in the Mediterranean is complicated. Both A. saxatilis and A. vaigensis have 
often been found in places with shipping activities (see for example Malta and Genoa) or aquarium releases are likely (see Palamos in Spain, where further aquarium releases have been recently detected). Mediterranean findings of these species are separated by large distances and no clear geographical pattern can be highlighted. The small size of Abudefduf spp. would also fit with the idea of direct human transportation (E. Azzuro, pers. Comm.). However, as natural range expansion cannot be excluded, we have not included A. saxatilis in our list.

Kyphosus spp.: two, perhaps three, Kyphosus species- K. bigibbus Lacepéde, 1801, K. sectatrix (Linnaeus, 1758) and K. vaigiensis (Quoy and Gaimard, 1825) have been occasionally recorded in the Mediterranean. These species occur both in the Atlantic and Indo-Pacific regions, but it is likely that they entered the Mediterranean through the Strait of Gibraltar. However, it is unclear whether they have established reproductive native populations in the Mediterranean (Mannino et al., 2015).

\subsection{TAXONOMIC/NOMENCLATURAL issues}

Nomenclatural discrepancies were noted in 26 cases (Table 1).

Following a major revision of Bivalvia (Huber, 2015), Mollusca is the taxonomic group with the most nomenclatural changes. For example, two Timoclea species are known as Mediterranean immigrants: Timoclea djiboutiensis (F. P. Jousseaume, 1894), so far only known from Tunisia, and Timoclea roemeriana (Issel, 1869) only known from the Eastern Mediterranean, but not Timoclea marica (Linnaeus, 1758) that does not even occur in the Red Sea (Huber, 2015).

The following species are alien species but have doubtful taxonomic entities: Amphioctopus cf. aegina (Gray, 1849), Acanthopleura sp.; Botrytella "cf. parva". C. brunnea (Hincks, 1884) found in 2004 in Turkey (as reported in Galil et al., 2016) is probably Celleporaria sp. aff. brunnea and was found in Lebanon (Harmelin, 2014).

Based on additional morphological and a phylogenetic data, Pelagia benovici Piraino, Aglieri, Scorrano \& Boero, 2014, a jellyfish recently described from the Northern Adriatic, has been assigned to the genus Mawia [renamed as Mawia benovici (Piraino, Aglieri, Scorrano and Boero, 2014) (Avian et al., 2016)].

\subsection{Changes in establishment success}

The terminology "Common, Local, Abundant, Rare" that is used to describe the establishment success may be misleading. Some species, which are reported as local, are in fact well established and widespread in the Mediterranean, or they may be local, yet abundant. Often, introduced ascidians have been reported from a few places, but in these places they can be tremendously abundant. In our list, we consider the establishment success not only in the country where they were first detected, but throughout the Mediterranean. Several examples of noted discrepancies are discussed here. Among macrophytes, Lithophyllum yessoense Foslie is well established and common in the Thau Lagoon and Sargassum muticum (Yendo) Fensholt can be classified as common/abundant (invasive) in several Mediterranean lagoons (MV, pers. observ.). Scytosiphon dotyi M.J.Wynne is established in Italy (Northern Adriatic); France, Spain and Turkey (Verlaque et al., 2015). Codium fragile subsp. fragile (Suringar) Hariot is established and abundant (localy invasive) in the Mediterranean (Verlaque et al., 2015).

The bivalve Septifer cumingii Recluz, 1849, the bryozoan Arbopercula tenella (Hincks, 1880), and the echinoderm Amphiodia (Amphispina) obtecta Mortensen, 1940 should be all listed as common.

Among polychaetes, Pseudonereis anomala Gravier, 1900 is an invasive AS, widely distributed in the Mediterranean Sea, from all Levant countries to Izmir and Sicily (Çinar and Ergen, 2005;

Table 1

Species whose nomenclature has been recently revised.

\begin{tabular}{|c|c|c|c|}
\hline Taxon & Species in Galil et al., 2016 & Valid name & Source/comment \\
\hline $\begin{array}{l}\text { Ochrophyta/ } \\
\text { Phaeophyceae }\end{array}$ & Botrytella parva (Takamatsu) H.S.Kim & Botrytella "cf. parva" & $\begin{array}{l}\text { It is likely to be B. parva but the identification requires } \\
\text { a genetic confirmation }\end{array}$ \\
\hline Mollusca & Crassostrea gigas (Thunberg, 1793) & Magallana gigas (Thunberg, 1793) & WoRMS \\
\hline Mollusca & Paphia textile (Gmelin, 1791) & Paratapes textilis (Gmelin, 1791) & Huber, 2015 \\
\hline Mollusca & Gafrarium pectinatum (Linnaeus, 1758) & Gafrarium savignyi (Jonas, 1846) & Huber, 2010 \\
\hline Mollusca & Tellina valtonis Hanley, 1844 & Nitidotellina unifasciata (G.B. Sowerby II, 1867) & Huber, 2015 \\
\hline Mollusca & Acanthopleura gemmata (Blainville, 1825) & Acanthopleura sp. & Crocetta et al., 2014 \\
\hline Mollusca & Circenita callipyga (Born, 1778) & Circenita varia (Forsskål in Niebuhr 1775) & Huber, 2015 \\
\hline Mollusca & Mytilopsis sallei (Recluz, 1849) & Mytilopsis adamsi J. P. E. Morrison, 1946 & Huber, 2015 \\
\hline Mollusca & Timoclea marica (Linnaeus, 1758) & Timoclea roemeriana (Issel, 1869) & Huber, 2015 \\
\hline Mollusca & Elysia grandifolia Kelaart, 1858 & Elysia ornata (Swainson, 1840) & Jensen, 2015 \\
\hline Mollusca & Amphioctopus aegina (Gray, 1849) & Amphioctopus cf. aegina (Gray, 1849) & Crocetta et al., 2014 \\
\hline Polychaeta & Pherusa saldanha Day, 1961 & Stylarioides grubei Salazar-Vallejo, 2011 & Misidentification Zenetos et al., 2012 \\
\hline Crustacea & $\begin{array}{l}\text { Macrophthalmus (Macrophthalmus) graeffei A. } \\
\text { Milne-Edwards, } 1873\end{array}$ & Macrophthalmus indicus Davie, 2012 & Davie, 2012 \\
\hline Crustacea & $\begin{array}{l}\text { Gonioinfradens paucidentatus (A. Milne- } \\
\text { Edwards, 1861) }\end{array}$ & $\begin{array}{l}\text { Charybdis (Gonioinfradens) paucidentatus (A. } \\
\text { Milne-Edwards, 1861) }\end{array}$ & WoRMS \\
\hline Bryozoa & Celleporaria brunnea (Hincks, 1884) & Celleporaria sp. aff. brunnea & Harmelin, 2014 \\
\hline Bryozoa & Electra tenella (Hincks, 1880) & Arbopercula tenella (Hincks, 1880) & Rosso and Di Martino, 2016 \\
\hline Fish & Apogon queketti Gilchrist, 1903 & Jaydia queketti (Gilchrist, 1903) & Golani et al., 2016 (CIESM) \\
\hline Fish & Apogon smithi (Kotthaus, 1970) & Jaydia smithi Kotthaus, 1970 & Golani et al., 2016 (CIESM) \\
\hline Fish & Atherinomorus lacunosus (Forster, 1801) & Atherinomorus forskali (Rüppell, 1838) & Golani et al., 2016 (CIESM) \\
\hline Fish & Lagocephalus spadiceus (Richardson, 1845) & Lagocephalus guentheri Miranda Ribeiro, 1915 & Misidentification: Matsuura et al., 2011 \\
\hline Fish & Pempheris vanicolensis Cuvier, 1831 & $\begin{array}{l}\text { Pempheris rhomboidea Kossmann and R£uber, } \\
1877\end{array}$ & Misidentification: Azzurro et al., 2015 \\
\hline Fish & Oxyurichthys papuensis (Valenciennes, 1837) & Oxyurichthys petersi (Klunzinger, 1871) & Golani et al., 2016 (CIESM) \\
\hline Fish & Bregmaceros atlanticus Goode and Bean, 1886 & Bregmaceros nectabanus Whitley 1941 & Misidentification: Harold and Golani, 2016 \\
\hline $\begin{array}{l}\text { Cnidaria/ } \\
\text { Hydrozoa }\end{array}$ & Sertularia thecocarpa (Jarvis, 1922) & Sertularia tongensis (Stechow, 1919) & WoRMS \\
\hline $\begin{array}{l}\text { Cnidaria/ } \\
\text { Scyphozoa }\end{array}$ & $\begin{array}{l}\text { Pelagia benovici Piraino, Aglieri, Scorrano \& } \\
\text { Boero, } 2014\end{array}$ & $\begin{array}{l}\text { Mawia benovici (Avian, Ramsak, Tirelli, } \\
\text { D'Ambra and Malej, 2016) }\end{array}$ & Avian et al., 2016 \\
\hline Ctenophora & Beroe ovata Bruguiẻre, 1789 & Beroe ovata sensu Mayer & WoRMS \\
\hline
\end{tabular}


D'Alessandro et al., 2016). It forms dense populations (up to 2500 ind. $\mathrm{m}^{-2}$ ) in shallow-water benthic habitats along the Levantine coasts and presumably is in competition with the native neredid species, such as Perinereis cultrifera (Grube, 1840) and Platynereis dumerilii (Audouin and Milne Edwards, 1834) (Çinar and Altun, 2007). Branchiomma bairdi is a common and abundant AS in the Eastern and Western Mediterranean Sea, reaching up to 50 ind. $\mathrm{m}^{-2}$ in the harbour environment (Arias et al., 2013b) and coastal lakes (Giangrande et al., 2012).

Among ascidians, Didemnum vexillum Kott 2002 was first reported in the Venice Lagoon (Tagliapietra et al., 2012) and later in the Ebro Delta (Spain, Ordonez et al., 2015). In these localities the species was highly abundant and has become a pest on bivalve cultures. It can be considered a species in expansion in the Mediterranean, a worrisome perspective given the harmful effects of this species in other areas (Lambert, 2009, and references therein). Herdmania momus (Savigny, 1816) should be also listed as common (Shenkar and Loya, 2008).

Among Cnidaria, Sertularia marginata (Kirchenpauer, 1864) seems to be widespread (Egypt, Israel, Lebanon, Syria, Turkey, Greece, and Morocco, see Gonzalez-Duarte et al., 2013).

Among fishes, Terapon puta Cuvier, 1829 and Pomadasys stridens (Forsskål, 1775) have become prevalent on the Israeli coast in the last few years (Golani, unpublished data). Moreover, Decapterus russelli (Rüppell, 1830), Pelates quadrilineatus (Bloch, 1790), Torquigener flavimaculosus Hardy and Randall, 1983, Hippocampus fuscus Rüppell, 1838 and Ostorhinchus fasciatus (White, 1790) are common and widespread in the Levantine basin (see EASIN). Pterois miles (Bennett, 1828), not only is non-rare but has become invasive in the Levantine basin (Lebanon, Turkey, Cyprus, and Greece: Crocetta et al., 2015b; Kletou et al., 2016; Dailianis et al., 2016).

To avoid misconception in defining the degree of establishment of a species, it is suggested to use the terminology presented in Blackburn et al. (2011). This hierarchical classification allows expression of the range of establishments from a casual record through to full naturalisation.

\subsection{First observation details}

\subsubsection{Year and country of first record}

Most of the disagreements on the first recipient country coincide with disagreement on the year of first sighting. Thus, out of 53 corrections that were spotted in the first recipient country, 48 are also attributed to deviation in the introduction date. Most discrepancies are due to quoting the publication date, and not looking for the exact collection date in the papers (i.e. Moazzo, 1939)/or not carefully reading the paper e.g. for Bryozoans in Harmelin et al. (2009). Some discrepancies are due to the fact that they are based on the first publication, while the first collection date was reported later. This applies for instance to the decapod Actaea savignii (H. Milne Edwards, 1834) first found in 2006 in Lebanon (Crocetta and Bariche in Crocetta et al., 2015b), but not in 2010 in Israel (Karhan et al., 2013); The macroalgae Cladophora patentiramea (Montagne) Kützing was first found in 1991 in Cyprus, Lomentaria hakodatensis Yendo in 1978 in France, and Uronema marinum Womersley in 1989 in France (Verlaque et al., 2015). Another sound case is that of the invasive macroalga Caulerpa cylindracea Sonder. The correct year and country of first observation is 1985 in Tunisia and not 1990 in Libya (Hamza et al., 1995; Sghaier et al., 2016). In addition to such inaccurate accounts, a plethora of missing resources was noted from national lists and databases (e.g. MAMIAS, ELNAIS). For example, many records in ELNAIS (Zenetos et al., 2015) were ignored. As an example the bivalve molluscs Pseudochama corbierei (Jonas, 1846) has been included in ELNAIS with its source and introduction date. However, the introduction date was ignored. The following cases are noteworthy for crustaceans:

$\checkmark$ Amphibalanus reticulatus (Utinomi, 1967): was first sighted in 2003 in Israel. The French record in 1977 was not in the wild, but relates to specimens found on the keel of a ship that sailed from the Indian Ocean to Toulon Harbour (France) through the Red Sea;

$\checkmark$ Plagusia squamosa (Herbst, 1790): was first found in 1968 in Lebanon. The 1873 record of this species in France was from a ship hull.

\section{For Ascidiacea:}

$\checkmark$ Symplegma brakenhielmi (Michaelsen, 1904): should be 1975 according to the museum samples at TAU, or 1999 according to Izquierdo-Munoz et al. (2009);

$\checkmark$ Styela plicata (Lesueur, 1823): Heller 1877 as Styela gyrosa. Traustedt 1883 mentions it in the Naples Gulf with the name Styela plicata (but, he lists Styela gyrosa of Heller as a synonym).

Finally, a few date changes are attributed to direct communication with the authors. Among them. Monotygma fulva (A. Adams, 1853) was corrected according to pers. comm by J.J.Van Aartsen; Septifer cumingii Recluz, 1849, according to pers. comm. by S. Albayrak.

The list published by Galil et al. (2016) includes 124 mistakes out of 614 records (20\%) in first country and/or collection date, 9 of which refer to non-established (NE) species (Table 2). Details per taxonomic group are in Table 2. Most discrepancies were noticed in Mollusca (36 established, 3 non established) and Macroalgae (27 establishedp2 non established), followed by Crustacea (13 establishedp1 non established); Fish (12 establishedp2 non established), and Polychaeta (13), Ascidiacea (4 establishedp1 non established), Bryozoa (3), other invertebrates (7). Consequently, it is inevitable to question the accuracy of data that the authors claim and the conclusions derived from those data.

\subsubsection{Trends in introduction}

The trend in new AS is used as a proxy of the trends of the invasive AS (IAS) in marine environments. Any increasing trend in the presence and abundance of AS in a given ecosystem, independently of their real impact, should be qualified as negative, whereas negative trends or stable situations, even if the environmental status cannot be defined as positive could be considered, at least, as acceptable. Any definition of Good Environmental Status (GES) in reference to descriptor 2 should be linked to the achievement of the GES in the biodiversity descriptors, in such a way that the environmental status in relation to AS would be defined as negative, if it is also negative for these other descriptors, and vice-versa (EEA, 2015). In our study, trend in new AS introductions was calculated on a decadal basis. We considered the decades of first introductions because the first observations have been mostly accidental. Recording a new AS requires either targeted research or the collaboration of an observer with a taxonomist. Consequently, the first sighting of an AS in a region (date and place) has often nothing to do with the true date and the place of its first introduction. Therefore, the exact date of the first observation is of low interest in setting the post-introduction dynamics, because the decade is usually sufficient.

By 1950 , it is estimated that 145 AS had been introduced ino the Mediterranean, 127 of which are established today. Fig. 1 demonstrates an increase in the rate of introductions after 1950 (sum of established and non-established species), which climbed to 17 species per year in the 2001 e2010 period and decreased after 2010. This latter could be partly attributed to a time lapse between the 
Table 2

Discrepancies in first collection/observation date and country. The revised data are in bold. The non-established species are in gray-colour shading.

\begin{tabular}{|c|c|c|c|}
\hline Macroalgae & Acrothamnion preissii (Sonder) E.M.Wollaston & $1966 \mathrm{e} 69$ & Italy \\
\hline macroalgae & Asparagopsis taxiformis [lineage 2] (Delile) Trevisan de Saint-Leon & 1993 & Spain \\
\hline macroalgae & Bonnemaisonia hamifera Hariot & 1909 & Tunisia \\
\hline macroalgae & Caulerpa cylindracea Sonder & 1985 & Tunisia \\
\hline macroalgae & Chondria curvilineata F.S.Collins \& Hervey & 1980 & Greece \\
\hline macroalgae & Cladophora patentiramea (Montagne) Kützing & 1991 & Cyprus \\
\hline macroalgae & Codium fragile subsp. fragile (Suringar) Hariot & 1946 & France \\
\hline macroalgae & Codium taylorii P.C.Silva & 1955 & Israel \\
\hline macroalgae & Colaconema codicola (Børgesen) H.Stegenga, J.J.Bolton \& R.J.Anderson & 1952 & France \\
\hline macroalgae & Derbesia rhizophora Yamada & 1984 & France \\
\hline macroalgae & Derbesia boergesenii (Iyengar \& Ramanathan) Mayhoub & 1972 & Syria \\
\hline macroalgae & Fucus spiralis Linnaeus & 1987 & France \\
\hline macroalgae & Galaxaura rugosa (J.Ellis \& Solander) J.V.Lamouroux & 1990 & Syria \\
\hline macroalgae & Hypnea anastomosans Papenfuss, Lipkin \& P.C.Silva & 1972 & Israel \\
\hline macroalgae & Hypnea cornuta (Kützing) J.Agardh & 1894 & Greece \\
\hline macroalgae & Hypnea valentiae (Turner) Montagne & 1996 & France \\
\hline macroalgae & Laurencia okamurae Yamada & 1984 & France \\
\hline macroalgae & Leathesia marina (Lyngbye) Decaisne & 1905 & France \\
\hline macroalgae & Lomentaria hakodatensis Yendo & 1978 & France \\
\hline macroalgae & Plocamium secundatum (Kützing) Kützing & 1976 & Spain \\
\hline macroalgae & Polysiphonia morrowii Harvey & 1997 & France \\
\hline macroalgae & Pterosiphonia tanakae S.Uwai \& M.Masuda & 1993 & France \\
\hline macroalgae & Sarconema filiforme (Sonder) Kylin & 1944 & Israel \\
\hline macroalgae & Sarconema scinaioides Børgesen & 1945 & Israel \\
\hline macroalgae & Scytosiphon dotyi M.J.Wynne & 1960 e 77 & Italy \\
\hline macroalgae & Spatoglossum variabile Figari \& De Notaris & 1944 & Egypt \\
\hline macroalgae & Sphaerotrichia firma (E.S.Gepp) A.D.Zinova & 1970 & Turkey \\
\hline macroalgae & Ulva ohnoi M.Hiraoka \& S.Shimada & 2011 & Italy \\
\hline macroalgae & Uronema marinum Womersley & 1989 & France \\
\hline Mollusca & Acteocina mucronata (Philippi, 1849) & 1986 & Turkey/Lebanon \\
\hline Mollusca & Amathina tricarinata (Linnaeus, 1767) & 2000 & Turkey/Lebanon \\
\hline Mollusca & Anadara kagoshimensis (Tokunaga, 1906) & $1965 e 69$ & Italy \\
\hline Mollusca & Arcuatula perfragilis (Dunker, 1857) & 1934 & Egypt \\
\hline Mollusca & Bursatella leachii Blainville, 1817 & 1940 & Israel \\
\hline Mollusca & Cerithidium perparvulum (Watson, 1886) & 1992 & Turkey/Cyprus \\
\hline Mollusca & Chama asperella Lamarck, 1819 & 1993 & Turkey \\
\hline Mollusca & Conus fumigatus Hwass in Brugui è re, 1792 & 1974 e 76 & Libya \\
\hline Mollusca & Magallana gigas (Thunberg, 1793) & 1905 & Italy \\
\hline Mollusca & Cycloscalahyalina (G. B. Sowerby II, 1844) & 1992 & Cyprus \\
\hline Mollusca & Diodora ruppellii (G. B. Sowerby I, 1835) & 1939 & Israel \\
\hline Mollusca & Favorinus ghanensis Edmunds, 1968 & 2003 & Tunisia \\
\hline Mollusca & Finella pupoides A. Adams, 1860 & 1958 & Israel/Turkey \\
\hline Mollusca & Fulvia australis (G. B. Sowerby II, 1834) & 1937 & Israel \\
\hline Mollusca & Fulvia fragilis (Forsskål in Niebuhr, 1775) & 1934 & Egypt \\
\hline Mollusca & Godiva quadricolor (Barnard, 1927) & $1985 e 86$ & Italy \\
\hline Mollusca & Goniobranchus annulatus (Eliot, 1904) & 2000 & Lebanon \\
\hline Mollusca & Mactra olorina Philippi, 1846 & 1883 & Egypt \\
\hline Mollusca & Marginella glabella (Linnaeus, 1758) & 2009 & Spain \\
\hline Mollusca & Modiolus auriculatus (Krauss, 1848) & 1934 & Israel \\
\hline Mollusca & Monotygma fulva (A. Adams, 1853) & 2000 & Turkey \\
\hline Mollusca & Mya arenaria Linnaeus, 1758 & 1984 & Greece \\
\hline Mollusca & Notocochlis gualteriana ( $\mathrm{R}$ ecluz, 1844) & 1961 & Israel \\
\hline Mollusca & Oscilla galilae Bogi, Karhan and Yokeș, 2012 & $1992 e 95$ & Turkey \\
\hline Mollusca & Mytilopsis adamsi J. P. E. Morrison, 1946 & 2002 & Egypt \\
\hline Mollusca & Paratapes textile (J. F. Gmelin 1791) & 1948 & Israel \\
\hline Mollusca & Petricola fabagella Lamarck, 1818 & 1905 & Egypt \\
\hline Mollusca & Petricolaria pholadiformis (Lamarck, 1818) & 1985 & Greece \\
\hline Mollusca & Pseudochama corbierei (Jonas, 1846) & 1938 & Greece \\
\hline Mollusca & Pseudominolia nedyma (Melvill, 1897) & 1959 & Israel \\
\hline Mollusca & Pseudorhaphitoma iodolabiata (Hornung and Mermod, 1929) & 2010 & Israel/Turkey \\
\hline Mollusca & Sabia conica (Schumacher, 1817) & 1954 & Israel \\
\hline Mollusca & Septifer cumingii Recluz, 1849 & 1999 & Turkey \\
\hline Mollusca & Siphonaria crenata Blainville, 1827 & 1934 & Egypt \\
\hline Mollusca & Spondylus spinosus Schreibers, 1793 & $1987 e 88$ & Israel \\
\hline Mollusca & Syphonota geographica (A. Adams and Reeve, 1850) & 1999 & Italy \\
\hline Mollusca & Syrnola lendix (A. Adams, 1863) & $1988 e 89$ & Turkey \\
\hline Mollusca & Tremoctopus gracilis (Eydoux and Souleyet, 1852) & 1937 & Croatia \\
\hline Mollusca & Trochus erithreus Brocchi, 1821 & 1968 & Israel \\
\hline Polychaeta & Ceratonereis mirabilis Kinberg, 1865 & 1969 & Egypt \\
\hline Polychaeta & Eusyllis kupfferi Langerhans, 1879 & 1998 & Cyprus \\
\hline Polychaeta & Glycinde bonhourei Gravier, 1904 & 1937 & Israel \\
\hline Polychaeta & Hesionura serrata (Hartmann-Schrøder, 1960) & 1978 & Spain \\
\hline Polychaeta & Leodice antennata Savigny in Lamarck, 1818 & $1975 e 81$ & Italy \\
\hline Polychaeta & Leonnates persicus Wesenberg-Lund, 1949 & 1968 & Egypt \\
\hline Polychaeta & Linopherus canariensis Langerhans, 1881 & 1965 & Lebanon \\
\hline
\end{tabular}


Table 2 (continued)

\begin{tabular}{|c|c|c|c|}
\hline Macroalgae & Acrothamnion preissii (Sonder) E.M.Wollaston & $1966 \mathrm{e} 69$ & Italy \\
\hline Polychaeta & Naineris setosa (Verrill, 1900) & 2003 & Italy \\
\hline Polychaeta & Notomastus mossambicus (Thomassin, 1970) & 1986 & Spain \\
\hline Polychaeta & Polycirrus twisti Potts, 1928 & 1983 & Greece \\
\hline Polychaeta & Streblosoma comatus (Grube, 1859) & 1975 e 76 & Italy \\
\hline Polychaeta & Streblospiogynobranchiata Rice and Levin, 1998 & 2002 & Turkey \\
\hline Polychaeta & Terebella ehrenbergi Gravier, 1906 & 1952 & France \\
\hline Crustacea & Actaea savignii (H. Milne Edwards, 1834) & 2006 & Lebanon \\
\hline Crustacea & Amphibalanus reticulatus (Utinomi, 1967) & 2003 & Israel \\
\hline Crustacea & Anilocra pilchardi Bariche and Trilles, 2006 & 2003 & Lebanon \\
\hline Crustacea & Bemlos leptocheirus (Walker, 1909) & 1924 & Egypt \\
\hline Crustacea & Calanopia elliptica (Dana, 1849) & 1891 & Italy \\
\hline Crustacea & Calanopia media Gurney, 1927 & 1924 & Egypt \\
\hline Crustacea & Callinectes sapidus Rathbun, 1896 & 1947 & Greece \\
\hline Crustacea & Cristapseudes omercooperi (Larwood, 1954) & 1947 & Palestine \\
\hline Crustacea & Hyastenus hilgendorfi de Man, 1887 & 1938 & Egypt \\
\hline Crustacea & Lernanthropus callionymicola El-Rashidy and Boxshall, 2012 & 1997 & Israel \\
\hline Crustacea & Myicola ostreae Hoshina and Sugiura, 1953 & 1972 & France \\
\hline Crustacea & Mytilicola orientalis Mori, 1935 & 1977 & France \\
\hline Crustacea & Plagusia squamosa (Herbst, 1790) & 1968 & Lebanon \\
\hline Crustacea & Pseudodiaptomus marinus Sato, 1913 & 2007 & Italy \\
\hline Ascidiacea & Botrylloides violaceus Oka, 1927 & 1991 & Italy \\
\hline Ascidiacea & Ecteinascidia styeloides (Traustedt, 1882) & 1983 & France \\
\hline Ascidiacea & Perophora multiclathrata (Sluiter, 1904) & 1983 & France \\
\hline Ascidiacea & Styela plicata (Lesueur, 1823) & 1877 & Italy \\
\hline Ascidiacea & Symplegma brakenhielmi (Michaelsen, 1904) & 1975 & Israel \\
\hline Bryozoa & Parasmittina egyptiaca (Waters, 1909) & 1993 & Lebanon \\
\hline Bryozoa & Parasmittina protecta (Thornely, 1905) & 2000 & Lebanon \\
\hline Bryozoa & Parasmittina serruloides Harmelin et al., 2009 & 1995 & Lebanon \\
\hline Echinodermata & Amphioplus (Lymanella) laevis (Lyman, 1874) & 1944 & Egypt \\
\hline Nematoda & Anguillicoloides crassus (Kuwahara, Niimi \& Itagaki, 1974) & 1980 & France \\
\hline Cnidaria & Campanularia morgansi Millard, 1957 & 2009 & Israel \\
\hline Cnidaria & Clytia linearis (Thorneley, 1900) & 1926 & Egypt \\
\hline Cnidaria & Diadumene lineata (Verrill, 1869) & 1925 & Italy \\
\hline Cnidaria & Eudendrium carneum Clarke, 1882 & 1950 & France \\
\hline Porifera & Paraleucilla magna Klautau, Monteiro \& Borojevic, 2004 & 2000 & Spain \\
\hline Fish & Chanos chanos (Forsskål, 1775) & 2011 & Turkey \\
\hline Fish & Equulites klunzingeri (Steindachner, 1898) & 1924 & Egypt \\
\hline Fish & Hyporhamphus affinis (Günther, 1866) & 1954 & Turkey \\
\hline Fish & Hippocampus fuscus Rüppell, 1838 & 1994 & Israel \\
\hline Fish & Lagocephalus suezensis Clark and Gohar, 1953 & 1975 & Lebanon \\
\hline Fish & Liza carinata (Valenciennes, 1836) & 1924 & Egypt \\
\hline Fish & Liza haematocheila (Temminck and Schlegel, 1845) & 1995 & Greece/Turkey \\
\hline Fish & Platycephalus indicus (Linnaeus, 1758) & 1902 & Egypt \\
\hline Fish & Sargocentron rubrum (Forsskål, 1775) & 1945 & Israel \\
\hline Fish & Saurida lessepsianus Russell et al., 2015 & 1951 & Turkey \\
\hline Fish & Sciaenops ocellatus (Linnaeus, 1766) & 1999 & Israel \\
\hline Fish & Siganus luridus (Rüppell, 1829) & 1931 & Syria \\
\hline Fish & Sillago suezensis Golani et al., 2014 & 1975 & Lebanon \\
\hline
\end{tabular}

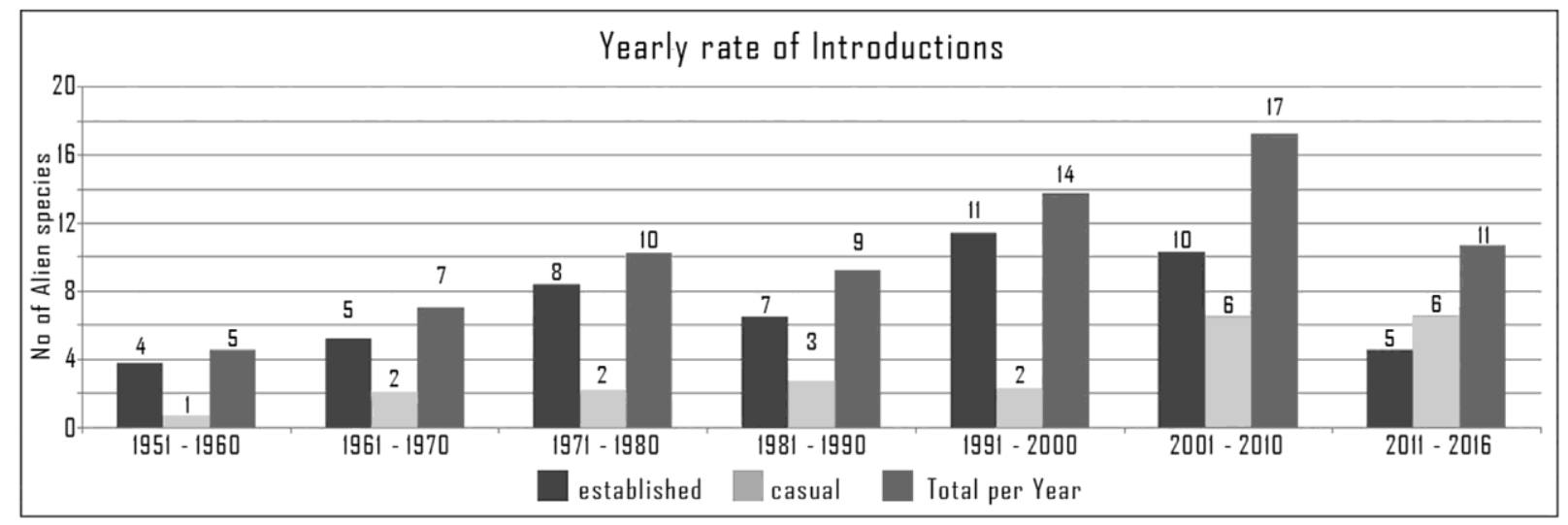

Fig. 1. Number of new AS per year at 10-yr intervals.

observation of the latest finding and publication. At subregional level, in 2015 it was estimated that the rate of new introductions of
AS during the period $2001 \mathrm{e} 2010$ was highest in the AegeanLevantine Sea $(\sim 17$ species per year), followed by the Ionian Sea 
and the Central Mediterranean Sea ( $~ 8$ species per year), and the Western Mediterranean Sea (with $\sim 7$ species per year) (EEA, 2015). The same conclusion has been reached in a series of works by Zenetos et al. (2005, 2008, 2010, 2012), each revising and updating the previous data, respectively.

When only the established species are considered, the peak of $\sim 11$ species per year accounts for the $1991 \mathrm{e} 2000$ period and falls to $\sim 5$ species per year after 2010. On the contrary, after 2000 the number of casual records appears to be steady (6 species per yr). It is expected that a number of the newly discovered species in the 2001 e2010 period will establish viable populations, leading to an increase of the established AS. However, a negative trend is obvious after 2010. A similar trend was illustrated, but not discussed, by Galil et al. (2016).

Is this negative trend in the established species a positive sign for the biodiversity of the Mediterranean? It could be. On the other hand, the increase in the previous decades could be the result of intensive scientific effort developed following the invasion of the much mediatized "killer alga" Caulerpa taxifolia (Vahl) C. Agardh in the 1990s.

3.4.2.1. Uncertainties. The uncertainties behind datasets on AS reflect the challenge of adequately discovering and reporting new species and mapping their distribution, but also of compiling data at a national/regional level.

Lists of invasive AS (IAS) are essential for preventing, controlling, and reporting on the state of biological invasions. However, these lists suffer from a range of errors, with serious consequences for their use in science, policy, and management (McGeoch et al., 2012). No checklist can be accurate by the time it is published. New data come to light and there are continuous changes on species nomenclature, likely date and pathway of introduction, origin, establishment success, and distribution of species. Consequently, every list could be called a 'provisional list'.

The list for Mediterranean AS is still an underestimate, for a number of reasons:

a) The present list does not include unicellular organisms. The diversity of marine microalgae is scarcely known in wide areas of the Mediterranean Sea. This makes it difficult to determine whether a suspected microalgal invader was already present as part of the rare, hidden and un-sampled phytoplankton. Therefore, phytoplankton has not been included in the analysis of the indicator;

b) Miscategorising AS species as native is not rare. The Suez Canal is relatively recent, but entries by vessels through Gibraltar have been occurring long before marine biologists started inventorying AS. Many pseudoindigenous species (Carlton, 2009) occur in the Mediterranean, precisely because many old taxonomic works originated in the Mediterranean, and what was there at the time of these initial inventories was assumed to be native, even if many species were described from ports and areas that were typical of introductions:

c) There are many records of new sightings that refer to species which are presently reported as cryptogenic. Phylogenetic studies have revealed that some of them are true aliens. Examples are reported in the section for 'Additional species'. Further studies will shed some light on the rest;

d) The alien status is still pending for many species that are presently categorised as 'questionable' (see Zenetos et al., 2010).

Inventories of the regional Online information systems (e.g. EASIN, MAMIAS) are difficult to keep up-to-date. Comparison of the present work with previous work (Zenetos et al., 2012) revealed an increase of approximately $28 \%$ in established AS during the previous 5 years [ $>600$ species vs. approximately 500 established species that were reported in Zenetos et al. (2012)].

With regards to the latest published list (Zenetos et al., 2010, 2012; Galil et al., 2016), the difference in the number of established AS per taxonomic groups is demonstrated in Fig. 2. The phyla with the highest increase since 2012 are the Bryozoa (108\% increase), followed by Ascidiacea (100\%) and Polychaeta (41\%). In the groups treated in the CIESM atlases (Galil et al., 2002; Golani et al., 2016; Verlaque et al., 2015; Zenetos et al., 2004) there seems to be a steady increase of approximately $20 \%$. Considering updates of the Galil et al. (2016) per taxonomic group, in decreasing order, they are major in Ascidiacea (58\% of taxa), Polychaeta (57\%), Macroalgae (49\%), Mollusca (45\%), Bryozoa (36\%), Crustacea (20\%), and these are values that reflect both the taxonomic expertise of the research group and their knowledge of the local biodiversity. It should be noted here that the phylum mollusca might need a further update. Some small sized gastropods species such as Voorwindia tiberiana

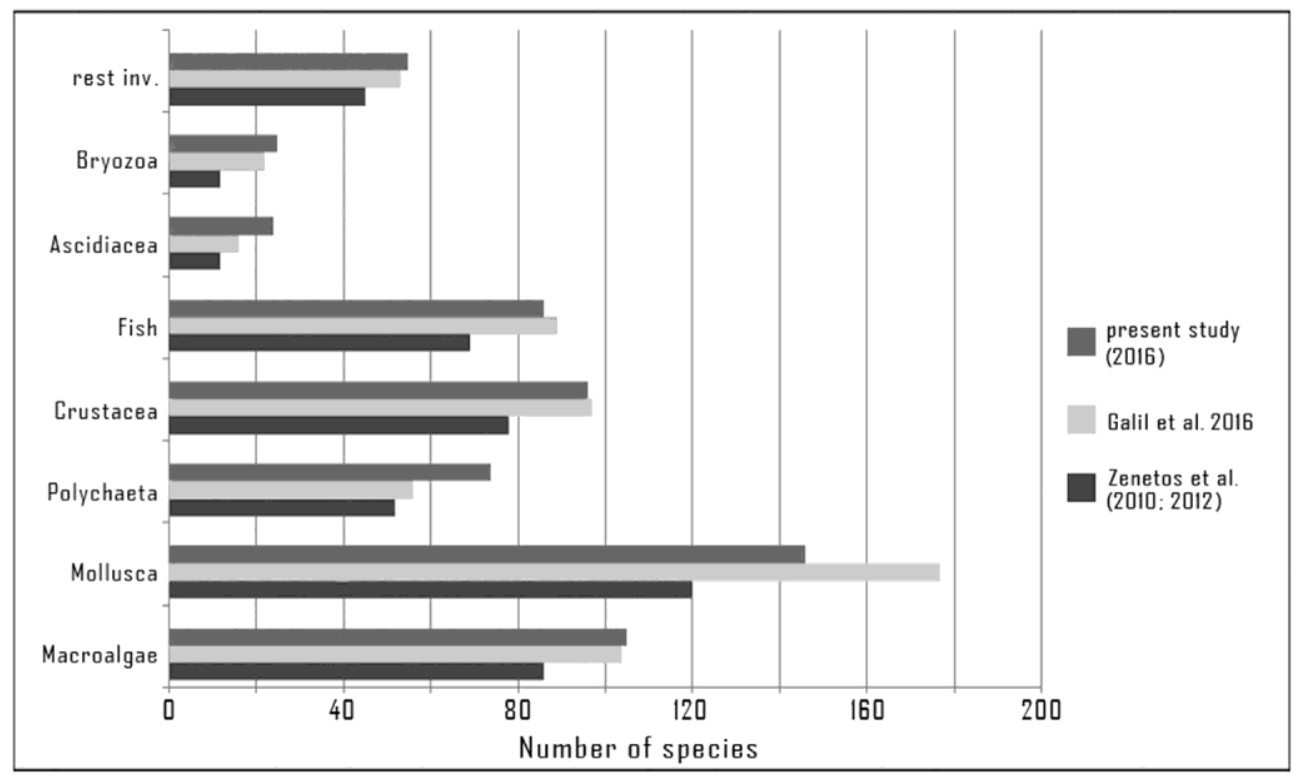

Fig. 2. Comparative number of AS in the recent body of literature. 
(Issel, 1869), Iolaea neofelixoides (Nomura, 1936) and Aliculastrum cylindricum (Helbling, 1779) that noted as rare or unknown in Galil et al. (2016), are not discussed here because their true distribution remains unknown. Following Mienis (2004) they are provisionally treated as established. Other taxomonic groups such as Cnidaria also need a further update.

Inconsistencies are also observed in comparing the present list with what is archived in EASIN v.5.7, Latest Update: 15/11/2016. This is inevitable due to changes that came to light after November 2016 and not only, but we are confident that EASIN and INVASIVESNET can play a major role in the future revision/update of the present list, which can currently serve for assessing indicators that are necessary for policy, and management of AS in the Mediterranean.

We fully agree with Galil et al. (2016) that current geographical, taxonomical and impact data gaps can be reduced only by instituting harmonised standards and methodologies for monitoring NIS populations in all countries bordering the Mediterranean Sea. However, their list is another 'provisional list' in which approximately $38 \%$ of the species need revision in one of the reported fields (Nomenclature, Year of first record, First recipient country, Population status), while a significant number $(>10 \%)$ of species are missing. Of the 72 added species, only 12 (4 macroalgae, 1 polychaete, 4 ascidians, 1 bryozoan, 2 cnidarians) were reported for the first time, or confirmed by genetic phylogeographic studies to be introduced, in 2016.

The present list reflects a team effort of regional experts in order to compile the most reliable source of information regarding the current status of invasive species in the Mediterranean. As professionals in this field, all authors of the present paper recognise the fact that even the current list may contain errors due to the dynamic nature of marine invasions, and the addition of new tools enabling accurate taxonomic identifications.

\section{Acknowledgements}

We would like to thank Dr. F. Monniot for providing us with first record dates and details for ascidians in her collection and Dr. Serhat Albayrak and J. Van Aartsen for first records for mollusca in his collection. The following colleagues provided details and valuable comments on the species: Dr. Geoff. A. Boxshall on the native status of Nothobomolochus fradei, Dr. Ernesto Azzuro on the status of Abudefduf spp, Dr. Maria Jesús Uriz concerning introduced sponge species and, Dr Luisa Borges for details on the occurrence of Teredothyra dominicensis.

This work was initiated during the DEVOTES (DEVelopment Of innovative Tools for understanding marine biodiversity and assessing good Environmental Status) project, funded by the European Union under the 7 th Framework Program (grant agreement no. 30839). The work of FC and AZ was partly funded by The East and South European Network for Invasive Alien Species - a tool to support the management of alien species in Bulgaria (ESENIASTOOLS) (European Economic Area funded - Contract No. D-33-51/ 30.06.2015). GS and FC were supported by STSM contracts in the framework of Alien Challenge COST Action (TD1209) funded by the European Commission.

\section{Appendix A. Supplementary data}

Supplementary data related to this article can be found at http:// dx.doi.org/10.1016/j.ecss.2017.03.031.

\section{References}

Albertelli, G., Chiantore, M., Drago, N., 1995. Macrobenthic assemblages in Pelagie
Islands and Pantelleria (Ionian Sea, Mediterranean). Oebalia 21, 115e123.

Alos, J., Tomas, F., Terrados, J., Verbruggen, H., Ballesteros, E., 2016. Fast-spreading green beds of recently introduced Halimeda incrassata invade Mallorca island (NW Mediterranean Sea). Mar. Ecol. Progr. Ser. 558, 153e158. http://dx.doi.org/ 10.3354/meps 11869 .

Aragay, J., Vitales, D., Gomez Garreta, A., Ribera Siguan, M.A., Steen, F., De Clerck, O., Garnatje, T., Rull Lluch, J., 2016. Phenological and molecular studies on the introduced seaweed Dictyota cyanoloma (Dictyotales, Phaeophyceae) along the Mediterranean coast of the Iberian Peninsula. Mediterr. Mar. Sci. 17 (3), 766e776. http://dx.doi.org/10.12681/mms.1872.

Arias, A., Paxton, H., 2014. Hidden diversity within the polychaete Onuphis eremita sensu lato (Annelida: Onuphidae)dredescription of O. eremita Audouin \& Milne-Edwards, 1833 and reinstatement of Onuphis pancerii Claparede, 1868. Zootaxa 3861 (2), 145e169. http://dx.doi.org/10.11646/zootaxa.3861.2.3.

Arias, A., Barroso, R., Anadon, N., Paiva, P.C., 2013a. On the occurrence of the fireworm Eurythoe complanata complex (Annelida, Amphinomidae) in the Mediterranean Sea with an updated revision of the alien Mediterranean amphinomids. Zookeys 337, 19e33. https://doi.org/10.3897/zookeys.337.5811.

Arias, A., Giangrande, A., Gambi, M.C., Anadon, N., 2013b. Biology and new records of the invasive species Branchiomma bairdi (Annelida: Sabellidae) in the Mediterranean Sea. Mediterr. Mar. Sci. 14 (1), 162e171. http://dx.doi.org/10.12681/ mms.363.

Avian, M., Ramsak, A., Tirelli, V., D'Ambra, I., Malej, A., 2016. Redescription of Pelagia benovici into a new jellyfish genus, Mawia, gen. nov., and its phylogenetic position within Pelagiidae (Cnidaria: Scyphozoa: Semaeostomeae). Invertebr. Syst. 30 (6), 523e546. http://dx.doi.org/10.1071/IS16010.

Azzurro, E., Goren, M., Diamant, A., Galil, B., Bernardi, G., 2015. Establishing the identity and assessing the dynamics of invasion in the Mediterranean Sea by the dusky sweeper, Pempheris rhomboidea Kossmann \& R\&uber, 1877 (Pempheridae, Perciformes). Biol. Invasions 17 (3), 815e826. http://dx.doi.org/10. 1007/s10530-014-0836-5.

Açik, S., 2011. Sipuncula from the southern coast of Turkey (eastern Mediterranean), with a new report for the Mediterranean Sea. Cah. Biol. Mar. 52, 313e329.

Balss, H., 1927. Zoological results of the Cambridge Expedition to the Suez Canal, 1924. XIV. Bericht über die Crustacea Decapoda (Natantia und Anomura). Trans. Zool. Soc. Lond. 22, $221 \mathrm{e} 227$.

Barash, A., Danin, Z., 1977. Additions to the knowledge of Indo-Pacific Mollusca in the Mediterranean. Conchiglie 13 (5e6), 85e116.

Barash, A., Danin, Z., 1986. Further additions to the knowledge of Indo-Pacific Mollusca in the Mediterranean Sea. Spixiana 9 (2), 117e141.

Barash, A., Danin, Z., 1992. Fauna Palaestina: Mollusca I. Annotated List of Mediterranean Molluscs of Israel and Sinai. The Israel Academy of Sciences and Humanities, Jerusalem.

Ben-Eliahu, M.N., 1972. Polychaeta Errantia of the Suez Canal. Isr. J. Zool. 21 (3e4), 189 e237.

Ben-Eliahu, M.N., 1976. Errant polychaete cryptofauna (excluding Syllidae and Nereidae) from rims of similar intertidal vermetid reefs on the Mediterranean coast of Israel and in the Gulf of Elat. Isr. J. Zool. 25 (4), $156 e 177$.

Ben-Eliahu, M.N., 1991. Nereididae of the Suez CanalePotential Lessepsian migrants? Bull. Mar. Sci. 48, 318 e 329.

Bettoso, N., Comisso, G., 2015. First record of the Chinese mitten crab (Eriocheir sinensis) in the Lagoon of Marano and Grado (Northern Adriatic Sea). Ann. Ser. Hist. Nat. 25, 29e34

Blackburn, T.M., Pysek, P., Bacher, S., Carlton, J.T., Duncan, R.P., Jarosík, V., Wilson, J.R.U., Richardson, D.M., 2011. A proposed unified framework for biological invasions. Trends Ecol. Evol. 26 (7), 333e339. http://dx.doi.org/10.1016/j. tree.2011.03.023.

Bock, D.G., MacIsaac, H.J., Cristescu, M.E., 2012. Multilocus genetic analyses differentiate between widespread and spatially restricted cryptic species in a model ascidian. Proc. R. Soc. B 279, 2377e2385. http://dx.doi.org/10.1098/rspb.2011. 2610 .

Bogdanos, C., Satsmadjis, J., 1983. The macrozoobenthos of an Aegean embayment. Thalassographica 6,77 e105.

Bogi, C., Cianfanelli, S., Talenti, E., 1989. La malacofauna dell' Isola di Cipro. p. 187e214. In: Nofroni, I. (Ed.), Atti Prima Giornata di Studi Malacologici C.I.S.MA. Centro Italiano di Studi Malacologi. Roma, Italy.

Bouchemousse, S., Bishop, J.D.D., Viard, F., 2016. Contrasting global genetic patterns in two biologically similar, widespread and invasive Ciona species (Tunicata, Ascidiacea). Sci. Rep. 6 (24875). http://dx.doi.org/10.1038/srep24875.

Boudouresque, C.-F., Ben Souissi, J., Perret-Boudouresque, M., Verlaque, M., 2016. The Red Sea macroalga Palisada maris-rubri (Rhodobionta, Archaeplastida): first record in Tunisia. Rapp. Comm. Int. Mer. Medit. 41, 414.

Brunetti, R., Menin, F., 1977. Ascidians of the Laguna Veneta II. Distribution and ecological observations. Boll. Zool. 44, 337e352. http://dx.doi.org/10.1080/ 11250007709429273.

Brunetti, R., Gissi, C., Pennati, R., Caicci, F., Gasparini, F., Manni, L., 2015. Morphological evidence that the molecularly determined Ciona intestinalis type A and type B are different species: Ciona robusta and Ciona intestinalis. J. Zool. Syst. Evol. Res. 53, 186e193. http://dx.doi.org/10.1111/jzs.12101.

Buzzurro, G., Cecalupo, A., 2006. I molluschi lessepsiani di Tasucu (Turchia sudorientale): descrizione di Parviturbo dibellai n. sp. (Gastropoda: Trochoidea: Skeneidae). Boll. Malacol. 42 (1), 27 e32.

Cachia, C., Mifsud, C., Sammut, P.M., 2004. The Marine Mollusca of the Maltese Islands. Part Four. The Classes: Caudofoveata, Solenogastres, Bivalvia, Scaphopoda \& Cephalopoda. Backhuys Publishers, Leiden, The Netherlands, p. 270. 
Carlton, J.T., 1996. Biological invasions and cryptogenic species. Ecology 77 (6), 1653e1655. http://dx.doi.org/10.2307/2265767.

Carlton, J.T., 2009. Deep invasion ecology and the assembly of communities in historical time. In: Rilov, G., Crooks, J.A. (Eds.), Biological Invasions in Marine Ecosystems. Springer, Berlin, pp. 13 e56.

Çevik, C., Cavas, L., Erguden, D., Turan, C., 2012. A second observation of Dendrodoris fumata (Rüppell \& Leuckart, 1830) from the Mediterranean Sea (Nudibranchia: Dendrodorididae). Zool. Middle East 56 (1), 148e149. http://dx.doi.org/10.1080/ 09397140.2012 .10648954

Çinar, M.E., 2005. Polychaetes from the coast of northern Cyprus (eastern Mediterranean Sea), with two new records for the Mediterranean Sea. Cah. Biol. Mar. 46 (2), 143 e159.

Cinar, M.E., 2007. Re-description of Timarete punctata (Polychaeta: Cirratulidae) and its occurrence in the Mediterranean Sea. Sci. Mar. 71, 755e764. http://dx.doi. org/10.3989/scimar.2007.71n 4755 .

Çinar, M.E., 2008. Description of a new fireworm, Eurythoe turcica sp. nov. (Polychaeta: Amphinomidae), from the Levantine coast of Turkey (eastern Mediterranean), with re-descriptions of Eurythoe parvecarunculata Horst and Amphinome djiboutiensis Gravier based on type material. J. Nat. Hist. 42 (29e30), 1975e1990. http://dx.doi.org/10.1080/00222930802140194.

Çinar, M.E., 2009. Alien polychaete species (Annelida: Polychaeta) on the southern coast of Turkey (Levantine Sea, eastern Mediterranean), with 13 new records for the Mediterranean Sea. J. Nat. Hist. 43 (37e38), 2283e2328. http://dx.doi.org/ 10.1080/00222930903094654.

Çinar, M.E., 2013. Alien polychaete species worldwide: current status and their impacts. J. Mar. Biol. Assoc. U. K. 93 (5), 1257e1278. http://dx.doi.org/10.1017/ S0025315412001646.

Çinar, M.E., 2016. The alien ascidian Styela clava now invading the Sea of Marmara (Tunicata: Ascidiacea). Zookeys 563, 1e10. https://doi.org/10.3897/zookeys.563. 6836.

Çinar, M.E., Altun, C.A., 2007. A preliminary study on population characteristics of the Lessepsian species, Pseudonereis anomala (Polychaeta: Nereididae), in Iskenderun Bay (Levantine Sea, eastern Mediterranean). Turk. J. Zool. 31, 403 e410.

Çinar, M.E., Ergen, Z., 2005. Lessepsian migrants expanding their distributional ranges; Pseudonereis anomala (Polychaeta: Nereididae) in Izmir Bay (Aegean Sea). J. Mar. Biol. Assoc. U. K. 85, 313e321. http://doi.org/10.1017/ S0025315405011203h.

Çinar, M.E., Ergen, Z., 2007. The presence of Chaetozone corona (Polychaeta: Cirratulidae) in the Mediterranean Sea: an alien or a native species? Cah. Biol. Mar. 48 (4), 339e 346

Çinar, M.E., Fauchald, K., Dagli, E., 2014a. Occurrence of Diopatra marocensis (Annelida: Onuphidae) in the eastern Mediterranean. Zookeys 445, 1 e11. https://doi.org/10.3897/zookeys.445.8464.

Çinar, M.E., Yokes, M.B., Açik, S., Bakir, A.K., 2014b. Check-list of Cnidaria and Ctenophora from the coasts of Turkey. Turk. J. Zool. 38, 677e697. http://dx.doi.org/ 10.3906/zoo-1405-68.

Corbera, J., Galil, B.S., 2016. Cumacean assemblages on the Levantine shelf (Mediterranean Sea)espatiotemporal trends between 2005 and 2012. Mar. Biol. Res. 12 (6), 663e672. http://dx.doi.org/10.1080/17451000.2016.1169297.

Corsini-Foka, M., Zenetos, A., Crocetta, F., Çinar, M.E., Koçak, F., Golani, D., Katsanevakis, S., Tsiamis, K., Cook, E., Froglia, C., Triandaphyllou, M., Lakkis, S., Kondylatos, G., Tricarico, E., Zuljevic, A., Almeida, M., Cardigos, F., Çąlar, S., Durucan, F., Fernandes, A.M.D., Ferrario, J., Haberle, I., Louizidou, P., Makris, J., Maric, M., Micu, D., Mifsud, C., Nall, C., Kytinou, E., Poursanidis, D., Spigoli, D. Stasolla, G., Yapici, S., Roy, H.E., 2015. Inventory of alien and cryptogenic species of the Dodecanese (Aegean Sea, Greece): Collaboration through COST action training school. Manag. Biol. Invasions 6 (4), 351e366. http://dx.doi.org/10. 3391/mbi.2015.6.4.04.

Crocetta, F., Galil, B.S., 2012. The invasive spotted sea hare Aplysia dactylomela (Mollusca: Gastropoda: Aplysiidae)dnew records and spread pattern in the Mediterranean. Vie Milieu 62 (1), 43e46.

Crocetta, F., Renda, W., Vazzana, A., 2009. Alien Mollusca along the Calabrian shores of the Messina Strait area and a review of their distribution in the Italian Seas. Boll. Malacol. 45, 15e30.

Crocetta, F., Bitar, G., Zibrowius, H., Capua, D., Dell'Angelo, B., Oliverio, M., 2014. Biogeographical homogeneity in the eastern Mediterranean Sea e iii. New records and a state of the art of Polyplacophora, Scaphopoda and Cephalopoda (Mollusca) from Lebanon. Spixiana 37 (2), 183e206.

Crocetta, F., Mariottini, P., Salvi, D., Oliverio, M., 2015a. Does GenBank provide a reliable DNA barcode reference to identify small alien oysters invading the Mediterranean Sea? J. Mar. Biol. Assoc. U.K. 95 (1), 111e122. http://dx.doi.org/ $10.1017 /$ S0025315414001027.

Crocetta, F., Agius, D., Balistreri, P., Bariche, M., Bayhan, Y.K., Çakir, M., Ciriaco, S., Corsini-Foka, M., Deidun, A., El Zrelli, R., Ergüden, D., Evans, J., Ghelia, M.,

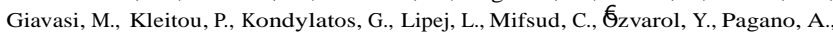
Portelli, P., Poursanidis, D., Rabaoui, L., Schembri, P.J., Tașkin, E., Tiralongo, F, Zenetos, A., 2015b. New Mediterranean biodiversity records (October 2015). Mediterr. Mar. Sci. 16 (3), 682e702. http://dx.doi.org/10.12681/mms.1477.

Dagli, E., Cinar, M.E., 2011. Species of the subgenus Minuspio (Polychaeta: Spionidae: Prionospio) from the southern coast of Turkey (Levantine Sea, eastern Mediterranean), with the description of two new species. Zootaxa 3043, 35e53.

Dailianis, T., Akyol, O., Babali, N., Bariche, M., Crocetta, F., Gerovasileiou, V., Ghanem, R., G€koglu, M., Hasiotis, T., Izquierdo-Munoz, A., Julian, D. Katsanevakis, S., Lipej, L., Mancini, E., Mytilineou, Ch, Ounifi Ben Amor, K.,

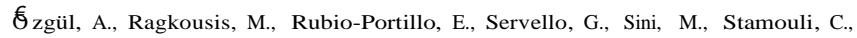
Sterioti, A., Teker, S., Tiralongo, F., Trkov, D., 2016. New Mediterranean biodiversity records (July 2016). Mediterr. Mar. Sci. 17 (2), 608e626. http://dx.doi, org/10.12681/mms.1734.

Davie, P.J.F., 2012. A review of Macrophthalmus sensu lato (Crustacea: Decapoda: Macrophtalmidae) from Australia, including two new species and new records. Mem. Queensl. Mus. Nat. 56 (1), 149e219.

Davis, M.H., Davis, M.E., 2008. First record of Styela clava (Tunicata, Ascidiacea) in the Mediterranean region. Aquat. Invasions 3 (2), 125e132. http://dx.doi.org/10. 3391/ai.2008.3.2.2.

Della Valle, A., 1877. Contribuzioni alla storia naturale delle Ascidie Composte del Golfo di Napoli con la descrizione di alcune specie e varieta nuove e di altre poco note. Tipografia Comuni, Napoli, p. 48.

Delle Chiaje, S., 1828. Memorie sulla storia e notomia degli animali senza vertebre del Regno di Napoli, vol. 3. Stamp. Societå Tipografica, Napoli, p. 232.

Deval, M.C., Kaya, Y., Güven, O., G€koylu, M., Froglia, C., 2010. An unexpected find of the Western Atlantic shrimp, Farfantepenaeus aztecus (Ives, 1891) (Decapoda, Penaeidae) in Antalya Bay, Eastern Mediterranean Sea. Crustaceana 83 (12), 1531e1537. http://dx.doi.org/10.1163/001121610X538859.

DiBattista, J.D., Randall, J.E., Bowen, B.W., 2012. Review of the round herrings of the genus Etrumeus (Clupeidae: Dussumieriinae) of Africa, with descriptions of two new species. Cybium 36 (3), 447 e460.

Dorgham, M.M., Hamdy, R., 2015. The role of alien polychaetes along the Alexandria Coast, Egypt. Int. J. Environ. Res. 9 (1), 141e150.

Dulcic, J., Pallaoro, A., Dragicevic, B., Staglicic-Radica, N., 2010. First record of dwarf flathead Elates ransonnetii [sic](Platycephalidae) in the Adriatic Sea. Cybium 34 (2), $222 e 223$

D'Alessandro, M., Castriota, L., Consoli, P., Romeo, T., Andaloro, F., 2016. Pseudonereis anomala (Polychaeta, Nereididae) expands its range westward: first Italian record in Augusta and Siracusa harbours. Mar. Biodivers. 46 (1), 129e133. http:// dx.doi.org/10.1007/s 12526-015-0334-8.

EEA, 2015. http://www.eea.europa.eu/data-and-maps/indicators/trends-in-marinealien-species-mas-2/assessment.

El-Rashidy, H.H., Boxshall, G.A., 2009. Parasites gained: alien parasites switching to native hosts. J. Parasitol. 95 (6), 1326e1329. http://dx.doi.org/10.1645/GE-2190. 1

El-Rashidy, H.H., Boxshall, G.A., 2010. Parasitic copepods on immigrant and native clupeid fishes caught in Egyptian coastal waters off Alexandria. Syst. Parasitol. 76, 19e38. http://dox.doi.org/10.1007/s 11230-010-9230-6.

Engl, W., Çeviker, D., 1999. New migrant species from southeast Turkey Psammotreta praerupta (Salisbury, 1934) and Antigona lamellaris Schumacher, 1817. La Conchiglia 290, 17e20.

Fauvel, P., 1927. Rapport sur les Annelides Polychẻtes Errantes. Trans. Zool.Soc. Lond. 22, 411e439. http://dx.doi.org/10.1111/j.1096-3642.1927.tb00203.x.

Fauvel, P., 1955. Contribution a la faune des Annelides Polychẻtes des côtes d'Israel. Sea Fish. Res. Stn. Haifa Bull. 10, 3e12.

Fehlauer-Ale, K.H., Mackie, J.A., Lim-Fong, G.E., Ale, E., Pie, M.R., Waeschenbach, A., 2014. Cryptic species in the cosmopolitan Bugula neritina complex (Bryozoa, Cheilostomata). Zool. Scr. 43, 193e205. http://dx.doi.org/10.1111/zsc.12042.

Fricke, R., Golani, D., Appelbaum-Golani, B., 2015. First record of the Indian anchovy Stolephorus indicus (van Hasselt, 1823) (Clupeiformes: Engraulidae) in the Mediterranean Sea. BioInvasions Rec. 4 (4), 293e297. http://dx.doi.org/10.3391/ bir.2015.4.4.11.

Galil, B.S., 2008. Alien species in the Mediterranean Seadwhich, when, where, why? Hydrobiologia 606 (1), 105e116. http://dx.doi.org/10.1007/s 10750-0089342-z.

Galil, B.S., 2009. Taking stock: inventory of alien species in the Mediterranean Sea Biol. Invasions 11, 359e372. http://dx.doi.org/10.1007/s 10530-008-9253-y. Galil, B.S., Froglia, C., No€l, P., 2002. CIESM Atlas of exotic species in the Mediterranean. In: Crustaceans: Decapods and Stomatopods, vol. 2. CIESM Publishers, Monaco.

Galil, B.S., Marchini, A., Occhipinti-Ambrogi, A., 2016. East is east and West is west? Management of marine bioinvasions in the Mediterranean Sea. Estuar. Coast. Shelf S. http://dx.doi.org/10.1016/j.ecss.2015.12.021.

Garilli, V., Vardala-Theodorou, E., 2005. Occurrence of the western Atlantic Cerithium litteratum (born, 1778) (Gastropoda: Cerithiidae) in the Aegean Sea. Not. SIM Boll. Malacol. Suppl. 23, 34e36.

Ghobashy, A.F.A., Abdel Messeih, M.K., 1991. Ascidians in Egyptian waters. J. Egypt Ger. Soc. Zool. 4, 313e326.

Giangrande, A., Gambi, M.C. 1982. Distribuzione dei Policheti nei fondi mobili della Rada di Augusta (Sicilia). Boll. Mus. Ist. Biol. Univ. Genova (Suppl. 50), 218 e222.

Giangrande, A., Cosentino, A., Lo Presti, C., Licciano, M., 2012. Sabellidae (Annelida) from the Faro coastal lake (Messina, Ionian Sea), with the first record of the invasive species Branchiomma bairdi along the Italian coast. Mediterr. Mar. Sci 13 (2), 283e293. http://dx.doi.org/10.12681/mms.310.

Golani, D., Fricke, R., Tikochinski, Y., 2014. Sillago suezensis, a new whiting from the northern Red Sea, and the status of Sillago erythraea Cuvier (Teleostei: Sillaginidae). J. Nat. Hist 48 (7e8), 413e428. http://dx.doi.org/10.1080/00222933. 2013.800609.

Golani, D., Sonin, O., Rubinstein, G., 2015. Records of Paralichthys lethostigma and Sciaenops ocellatus in the Mediterranean and Chana micropeltes in Lake Kinneret (Sea of Galilee), Israel. Mar. Biodivers. Rec. 8, e39. https://doi.org/10.1017/ S1755267215000081.

Golani, D., Orsi-Relini, L., Massutí, E., Quignard, J.-P., 2016. CIESM e Atlas of Exotic Fishes e List [WWW Document]. http://www.ciesm.org/atlas/appendix 1.html. 
Gonzalez-Duarte, M.M., Megina, C., Bethencourt, M., 2013. Sertularia marginata (Cnidaria: Hydrozoa) in the Mediterranean: an alien species in expansion? Mediterr. Mar. Sci. 14 (2), 384e389. http://dx.doi.org/10.12681/mms.445.

Goren, M., Galil, B.S., 1998. First record of the Indo-Pacific, coral reef fish Abudefduf vaigiensis (Quoy \& Gaimard, 1825) in the Levant. Isr. J. Zool. 44, 57e59.

Griggio, F., Voskoboynik, A., Iannelli, F., Justy, F., Tilak, M.-K., Turon, X., Pesole, G., Douzery, E.J.P., Mastrototaro, F., Gissi, C., 2014. Ascidian mitogenomics: comparison of evolutionary rates in closely related taxa provides evidence of ongoing speciation events. Genome Biol. Evol. 6, 591e605. https://doi.org/10. 1093/gbe/evu041.

Gurney, R., 1927. Report on the Crustacea. Copepoda (littoral and semiparasitic). Zoological results of the Cambridge expedition to the Suez Canal, 1924, no. 35 Trans. Zool. Soc. Lond. 22, 451 e577 figs. 108-168, tab. 35. (xii-1927).

Halim, Y., Abdel Messeih, M., 2016. Aliens in Egyptian waters. A checklist of ascidians of the Suez Canal and the adjacent Mediterranean waters. Egypt. J. Aquatic Res. http://dx.doi.org/10.1016/j.ejar.2016.08.004.

Hamza, A., Bradai, M.N., Ghorbel, M., Abdelmoulah, A., 1995. New mentions of Caulerpa racemosa (Forsskål) J. Agardh in the Gabẻs Gulf (Tunisia). Bull. Inst. Natl. Sci. Tech. Oceanogr. Pêche (Salammb仓) 22, 81 e88.

Harmelin, J.G., 2014. Alien bryozoans in the eastern Mediterranean Seadnew records from the coast of Lebanon. Zootaxa 3893 (3), 301e338. http://dx.doi.org/ 10.11646/zootaxa.3893.3.1.

Harmelin, J.G., Bitar, G., Zibrowius, H., 2009. Smittinidae (Bryozoa, Cheilostomata) from coastal habitats of Lebanon (Mediterranean sea), including new and nonindigenous species. Zoosystema 31 (1), 163e187. http://dx.doi.org/10.5252/ z2009n1a9.

Harmelin, J.G., Bitar, G., Zibrowius, H., 2016. High xenodiversity versus low native diversity in the south-eastern Mediterranean: bryozoans from the coastal zone of Lebanon. Mediterr. Mar. Sci. 17 (2), 417e439. http://dx.doi.org/10.12681/mms. 1429.

Harold, A.S., Golani, D., 2016. Occurrence of the Smallscale Codlet Bregmaceros nectabanus in the Mediterranean Sea, previously misidentified as B. atlanticus in this region. Mar. Biodivers.Rec 9 (1), 71. http://dx.doi.org/10.1186/s41200-0160071-0.

Heller, C., 1877. Untersuchungen über die Tunicaten des Adriatischen Meres. III. Denkschr, vol. 37. Akad, Wien, pp. 241 e275.

Hoffman, R., Wynne, M.J., 2016. Tetrasporangial plants of Monosporus indicus (Ceramiales, Rhodophyta): a new alien in the Mediterranean Sea. Eur. J. Phycol. 51 (4), 461e468. http://dx.doi.org/10.1080/09670262.2016.1208276.

Huber, M., 2010. Compendium of Bivalves. A Full-color Guide to 3,300 of the World's Marine Bivalves. A Status on Bivalvia after 250 Years of Research. ConchBooks, Hackenheim, Germany, p. 901.

Huber, M., 2015. Compendium of Bivalves 2. A Full-color Guide to the Remaining Seven Families. A Systematic Listing of 8,500 Bivalve Species and 10,500 Synonyms. ConchBooks, Harxheim, p. 907.

Izquierdo Munoz, A., Díaz Valdes, M., Ramos-Espla, A.A., 2009. Recent nonindigenous ascidians in the Mediterranean Sea. Aquat. Invasions 4 (1), 59 e64 http://dx.doi.org/10.3391/ai. 2009.4.1.5.

Jensen, K., 2015. Sacoglossa (Mollusca: Gastropoda: Heterobranchia) from northern coasts of Singapore. Raffles B. Zool. Suppl. 31, 226e249.

Karhan, S.Ü., Yokeș, M.B., Clark, P.F., Galil, B.S., 2013. First Mediterranean record of Actaea savignii (H. Milne Edwards, 1834) (Crustacea: Decapoda: Brachyura: Xanthidae), an additional Erythraean alien crab. BioInvasions Rec. 2 (2), 145e148. http://dx.doi.org/10.3391/bir.2013.2.2.09.

Kawai, H., Kogishi, K., Hanyuda, T., Arai, S., Gurgel, C.F., Nelson, W., Meinesz, A. Tsiamis, K., Peters, A.F., 2016. Phylogeographic analysis of the brown alga Cutleria multifida (Tilopteridales, Phaeophyceae) suggests a complicated introduction history. Phycol. Res. 64 (1), 3e10. http://dx.doi.org/10.1111/pre.12113.

Kinberg, J.G.H., 1857. Nya slfgten och arter af Annelider. $ॄ$ fversigt af K6niglich Vetenskapsakademiens f6rhandlingar, Stockholm 14(1), 11e14.

Kletou, D., Hall-Spencer, J.M., Kleitou, P., 2016. A lionfish (Pterois miles) invasion has begun in the Mediterranean Sea. Mar. Biodivers. Rec. 9 (46). http://dx.doi.org/ 10.1186/s41200-016-0065-y.

Knight-Jones, P., Knight-Jones, W., Ergen, Z., 1991. Sabelliform polychaetes, mostly from Turkey's Aegean coast. J. Nat. Hist. 25, 837e858. http://dx.doi.org/10.1080/ 00222939100770561.

Kott, P. 1985. The Australian Ascidiacea. Part 1, Phlebobranchia and Stolidobranchia Memoirs Qld. Mus. 23, 440

Kurt Sahin, G., 2014. Marphysa cinari, a new species of Eunicidae (Polychaeta) from the coasts of Turkey (eastern Mediterranean) and re-descriptions of Marphysa kinbergi McIntosh, 1910 and Marphysa disjuncta Hartman, 1961. J. Nat. Hist. 48 (33e34), 1989e2006. http://dx.doi.org/10.1080/00222933.2014.905125.

Lambert, G., 2009. Adventures of a sea squirt sleuth: unravelling the identity of Didemnum vexillum, a global ascidian invader. Aquat. Invasions 4 (1), 5 e28. http://dx.doi.org/10.3391/ai. 2009.4.1.2.

Laubier, L., 1966. Sur quelques Annelides Polychẻtes de la region de Beyrouth. Misc. Pap. Nat. Sci. Am. Univ. Beirut 5, 1 e15.

Le Garrec, V., Grall, J., Chevalier, C., Guyonnet, B., Jourde, J., Lavesque, N., Bonifacio, P., Blake, J.A., 2017. Chaetozone corona (Polychaeta, Cirratulidae) in the Bay of Biscay: a new alien species for rhe north-east Atlantic waters. J. Mar. Biol. Assoc. U. K. 97 (2), 433e445. http://dx.doi.org/10.1017/S0025315416000540.

Lejeusne, C., Bock, D.G., Therriault, T.W., MacIsaac, H.J., Cristescu, M.E., 2011 Comparative phylogeography of two colonial ascidians reveals contrasting invasion histories in North America. Biol. Invasions 13, 635e650. http://dx.doi. org/10.1007/s 10530-010-9854-0.
Leydet, K.P., Hellberg, M.E., 2015. The invasive coral Oculina patagonica has not been recently introduced to the Mediterranean from the western Atlantic. BMC Evol. Biol. 15 (1), 79. http://dx.doi.org/10.1186/s12862-015-0356-7.

Lopez-Legentil, S., Turon, X., Planes, S., 2006. Genetic structure of the star sea squirt, Botryllus schlosseri, introduced in southern European harbours. Mol. Ecol. 15, 3957e3967. http://dx doi.org/10.1111/j.1365-294X.2006.03087x.

Lopez-Legentil, S., Legentil, M.L., Erwin, P.M., Turon, X., 2015. Harbor networks as introduction gateways: contrasting patterns of native and introduced ascidians. Biol. Invasions 17, 1623e1638. http://dx.doi.org/10.1007/s10530-014-0821-z.

Lucy, F.E., Roy, H., Simpson, A., Carlton, J.T., Hanson, J.M., Magellan, K. Campbell, M.L., Costello, M.J., Pagad, S., Hewitt, C.L., McDonald, J., Cassey, P., Thomaz, S.M., Katsanevakis, S., Zenetos, A., Tricarico, E., Boggero, A., Groom, Q.J., Adriaens, T., Vanderhoeven, S., Torchin, M., Hufbauer, R., Fuller, P., Carman, M.R., Conn, D.B., Vitule, J.R.S., Canning-Clode, J., Galil, B.S., Ojaveer, H., Bailey, S.A., Therriault, T.W., Claudi, R., Gazda, A., Dick, J.T.A., Caffrey, J., Witt, A., Kenis, M., Lehtiniemi, M., Helmisaari, H., Panov, V.E., 2016. INVASIVESNET towards an International Association for open knowledge on invasive alien Species. Manag. Biol. Invasion 7 (2), 131e139. http://dx.doi.org/10.3391/mbi.2016.7.2.01.

Mannino, A.M., Balistreri, P., Iaciofano, D., Galil, B.S., Lo Brutto, S., 2015. An additional record of Kyphosus vaigiensis (Quoy \& Gaimard, 1825) (Osteichthyes, Kyphosidae) from Sicily clarifies the confused situation of the Mediterranean kyphosids. Zootaxa 3963 (1), 045e054. http://dx.doi.org/10.11646/zootaxa. 3963.1.3.

Mannino, A.M., Parasporo, M., Crocetta, F., Balistreri, P., 2016. An updated overview of the marine alien and cryptogenic species from the Egadi Islands Marine Protected Area (Italy). Mar. Biodivers. http://dx.doi.org/10.1007/s12526-0160496-z.

Marchini, A., Galil, B.S., Occhipinti-Ambrogi, A., 2015. Recommendations on standardizing lists of marine alien species: lessons from the Mediterranean Sea Mar. Pollut. Bull. 101 (1), 267e273. http://dx.doi.org/10.1016/j.marpolbul.2015. 09.054 .

Mastrototaro, F., Carlucci, R., Capezzuto, F., Sion, L., 2007. First record of dwar flathead Elates ransonnetii (Platycephalidae) in the Mediterranean Sea (North western Ionian Sea). Cybium 31 (3), 393 e394.

Matsuura, K., Golani, D., Bogorodsky, S.V., 2011. The first record of Lagocephalus guentheri Miranda Ribeiro, 1915 from the Red Sea with notes on previous re cords of L. lunaris (Actinopterygii, Tetraodontiformes, Tetraodontidae). Bull. Natl. Mus. Nat. Sci. Ser. A 37 (3), $163 e 169$.

McGeoch, M.A., Spear, D., Kleynhans, E.J., Marais, E., 2012. Uncertainty in invasive alien species listing. Ecol. Appl. 22 (3), 959e971. http://dx.doi.org/10.1890/11 1252.1.

Mienis, H.K., 1977. Cerithium nesioticum Pilsbry \& Vanatta, 1906. Another IndoPacific species from the Mediterranean coast of Israel. Conchiglie 13 (1e2), 45.

Mienis, H.K., 1980. A record of the indo-pacific species Trapezium oblongum from the Mediterranean coast of Israel. Levantina 27, 313e314.

Mienis, H.K., 1986. A record of Natica gualteriana, an Indo-Pacific species, from the Mediterranean coast of Israel. Levantina 60, 655e656.

Mienis, H.K., 2000. A second record of Notocochlis gualteriana from the Mediterranean coast of Israel. Triton 2, 24.

Mienis, H.K., 2001. Marine molluscs from the Eastern Mediterranean 5. first finds Canarium mutabilis. Spirula 323, 118 .

Mienis, H.K., 2003. Cantharus tranquebaricus first records of another Indian Ocean species in the Eastern Mediterranean. Triton 8, 11.

Mienis, H.K., 2004. New data concerning the presence of Indo-Pacific molluses in the Mediterranean Sea with emphasis on Israel. In: Є̂ztürk B., Salman A. (Eds.), Proceedings 1st National Malacology Congress, 1 e3 September 2004, Izmir. Turkish Journal of Aquatic Life 2(2), 117e131.

Mienis, H.K., 2006. Marine molluscs from the Eastern Mediterranean 26. The first finds of Thais sacellum (Gmelin, 1791) in Israel. Spirula 349, 27e28.

Mienis, H.K., Rittner, O., Rilov, G., Almogi, O., 2012a. Some additional records of two hardly known lessepsian migrants among the molluscs from the Mediterranean coast of Israel. Triton 26, 1 e3.

Mienis, H.K., Zaslow, R.B.-D., Rittner, O., 2012b. First records of Alectryonella plicatula from the Mediterranean coast of Israel (Mollusca, Bivalvia, Ostreidae). Triton 26, 4 e5.

Moazzo, P.G., 1939. Mollusques testaces marins du Canal de Suez. Mem.Inst. Egypte. Le Caire 38,1 e283.

Monniot, C., 1983. Ascidies littorals de Guadelope. II. Phlebobranches. Bull. Mus. natn Hist. Nat. Paris 4e Ser. 5, Sect. A 1, 51e71.

Monniot, F., 2016. Microcosmus anchylodeirus (Ascidiacea, Pyuridae) introduced in the Mediterranean Sea. Zootaxa 4175 (3), 222e230. http://dx.doi.org/10.11646/ zootaxa.4175.3.2.

Monniot, C., Monniot, F., 1987. Discussion sur la valeur de deux genres d'ascidies propos d'espẻces nouvelles en mediterranee. Ann. I.Oceanogr. Paris 63 (2), 119 e130.

Monro, C.C.A., 1937. A note on a collection of Polychaeta from the eastern Mediterranean with the description of a new species. Ann. Mag. Nat. Hist. 19, 82 e86.

Nishikawa, T., Oohara, I., Saitoh, K., Shigenobu, Y., Hasegawa, N., Kanamori, M., Baba, K., Turon, X., Bishop, J.D.D., 2014. Molecular and morphological discrimination between an invasive ascidian, Ascidiella aspersa, and its congener A. scabra (Urochordata: Ascidiacea). Zool. Sci. 31 (3), 180e185. http://dx.doi.org/ 10.2108/zsj.31.180

Nunes, A.L., Katsanevakis, S., Zenetos, A., Cardoso, A.C., 2014. Gateways to alien invasions in the European seas. Aquat. Invasions 9 (2), 133e144. http://dx.doi org/10.3391/ai.2014.9.2.02. 
Nydam, M.L., Giesbrecht, K.B., Stephenson, E.E., 2017. Origin and dispersal history of two colonial ascidian clades in the Botryllus schlosseri species complex. PLoS One 12 (1), e0169944. http://dx.doi.org/10.1371/journal.pone.0169944.

Ordonez, V., Pascual, M., Fernandez-Tejedor, M., Pineda, M.C., Tagliapietra, D., Turon, X., 2015. Ongoing expansion of the worldwide invader Didemnum vexillum (Ascidiacea) in the Mediterranean Sea: high plasticity of its biological cycle promotes establishment in warm waters. Biol. Invasions 17, 2075 e2085. http://dx.doi.org/10.1007/s10530-015-0861-z.

Ordonez, V., Pascual, M., Fernandez-Tejedor, M., Turon, X., 2016. When invasion biology meets taxonomy: Clavelina oblonga (Ascidiacea) is an old invader in the Mediterranean Sea. Biol. Invasions 18 (4), 1203e1215. http://dx.doi.org/10.1007/ s10530-016-1062-0.

Ounifi-Ben Amor, K., Rifi, M., Ghanem, R., Draeif, I., Zaouali, J., Ben Souissi, J., 2016. Update of alien fauna and new records from Tunisian marine waters. Mediterr. Mar. Sci. 17 (1), 124e143. http://dx.doi.org/10.12681/mms.1371.

Evzarol, Y., G6 koylu, M., 2012. First record of the Indo-Pacific milkfish, Chanos chanos (Forskål, 1775) in the Turkish Mediterranean Sea. Zool. Middle East 55, 135e136. http://dx.doi.org/10.1080/09397140.2012.10648930.

छztürk, B., Recevik, M., Geyran, K., 2015. New alien molluscs in the Mediterranean Sea. Cah. Biol. Mar. 56 (3), 205e212.

Pancucci-Papadopoulou, M.A., Zenetos, A., Corsini-Foka, M., Politou, C.Y., 2005. Update of marine alien species in Hellenic waters. Mediterr. Mar. Sci. 6 (2), 147e158. http://dx.doi.org/10.12681/mms.188.

Penas, A., Rolan, E., 2013. Revision of the genera Murchisonella and Pseudoaclisina (Gastropoda, Heterobranchia, Murchisonellidae). Vita Malacol. 11, 15 e64.

Pennati, R., Ficetola, G.F., Brunetti, R., Caicci, F., Gasparini, F., Griggio, F., Sato, A., Stach, T., Kaul-Strehlow, S., Gissi, C., Manni, L., 2015. Morphological differences between larvae of the Ciona intestinalis species complex: hints for a valid taxonomic definition of distinct species. PLoS One 10 (5), e0122879. http://dx. doi.org/10.1371/journal.pone.0122879.

Perẻs, J.M., 1958. Ascidies recoltees sur les côtes Mediterraneennes d'Israel. Bull. Res. Counc. Isr. 7B (3e4), 143e150.

Perez-Portela, R., Arranz, V., Rius, M., Turon, X., 2013. Cryptic speciation or global spread? The case of a cosmopolitan marine invertebrate with limited dispersal capabilities. Sci. Rep. 3 (3197). http://dx.doi.org/10.1038/srep03197.

Perrone, A.S., 1995. Una specie di Nudibranchi del genere Cuthona Alder \& Hancock, 1855, nuova per il Mediterraneo: Cuthona perca Marcus, 1958 (Opisthobranchia: Nudibranchia). Boll. Malacol. 31 (1e4), 28 e36.

Petit, G., 1960. Le "crabe chinois" est parvenu en Mediterranee. Vie Milieu 11, 133 e136.

Ramos-Espla, A.A., 1988. Ascidias litorales del Mediterraneo Iberico. Faunística, ecología y biogeografía. PhD Thesis. University of Barcelona, Spain.

Reem, E., Douek, J., Paz, G., Katzir, G., Rinkevich, B., 2017. Phylogenetics, biogeog raphy and population genetics of the ascidian Botryllus schlosseri in the Mediterranean Sea and beyond. Mol. Phylogenet. Evol. 107, 221e231. http://dx.doi org/10.1016/j.ympev.2016.10.005.

R€ckel, D., 1986. Sensational find in the Mediterranean. La Conchiglia 18 (210e211), 12

Rosso, A., Di Martino, E., 2016. Bryozoan diversity in the Mediterranean Sea: an update. Mediterr. Ma. Sci. 17 (2), 567e607. http://dx.doi.org/10.12681/mms. 1474.

Rothman, S.B.S., Goren, M., 2015. First record of the Red Sea shrimp-goby Cryptocentrus caeruleopunctatus in the Mediterranean Sea. Mar. Biodivers. Rec. 8, e157. http://dx.doi.org/10.1017/S1755267215001323.

Rubio, F., Rolan, E., Fernandez-Garces, R., 2015. Revision of the genera Parviturbo and Pseudorbis (Gastropoda, Skeneidae). Iberus 33, 167e259.

Rullier, F., 1963. Les Annelides polychẻtes du Bosphore, de la Mer de Marmara et de la Mer Noire, en relation avec celles de la Mediterranee. Rapp. Comm. Int. Mer Medit 17, 161e260.

Russell, B.C., Golani, D., Tikochinski, Y., 2015. Saurida lessepsianus a new species of lizardfish (Pisces: Synodontidae) from the Red Sea and Mediterranean Sea, with a key to Saurida species in the Red Sea. Zootaxa 3956 (4), 559e568. http://dx. doi.org/10.11646/zootaxa.3956.4.7.

Sami, M., Rym, E., Othman, J., Hechmi, M., 2014. First record of Pampus argenteus (Euphrasen, 1788) (Osteichthyes: Stromateidae) in Tunisian coast (Mediterranean sea). J.Mar. Biol. Oceanogr. 3 (1). http://dx.doi.org/10.4172/2324-8661. 1000123.

Savigny, J.-C., 1816. Memories sur les animaux sans vërtebres. Seconde Partie. Panckoucke C.L.F, Paris, p. 239.

Schellenberg, A., 1928. Report on the Amphipoda. Trans. Zool. Soc. Lond. 22, 633e692. http://dx.doi.org/10.1111/j.1096-3642.1928.tb00209.x.

Scorrano, S., Aglieri, G., Boero, F., Dawson, M.N., Piraino, S., 2016. Unmasking Aurelia species in the Mediterranean Sea: an integrative morphometric and molecular approach. Zool. J. Linn. Soc. http://dx.doi.org/10.1111/zoj.12494.

Scuderi, D., Russo, G.F., 2005. Prima segnalazione di Aplysia dactylomela Rang, 1828 e probabile presenza di Syphonota geographica (Adams and Reeve, 1850) (Gastropoda: Opisthobranchia: Anaspidea) per le acque del Mediterraneo. Biol Mar. Medit. 12 (1), 338e341

Sghaier, Y.R., Zakhama-Sraieb, R., Mouelhi, S., Vazquez, M., Valle, C., RamosEspla, A.A., Astier, J.M., Verlaque, M., Charfi-Cheikhrouha, F., 2016. Review of alien marine macrophytes in Tunisia. Mediterr. Mar. Sci. 17 (1), 109e123. http:// dx.doi.org/10.12681/mms.1366.

Sheets, E.A., Cohen, C.S., Ruiz, G.M., Rocha, R.M., 2016. Investigating the widespread introduction of a tropical marine fouling species. Ecol. Evol. 6 (8), 2453e2471. http://dx.doi.org/10.1002/ece3.2065.
Shenkar, N., Loya, y, 2008. The solitary ascidian Herdmania momus: native (Red Sea)versus non-indigenous (Mediterranean) populations. Biol. Invasions 10, 1431 e1439. http://dx.doi.org/10.1007/s10530-008-9217-2.

Sokolover, N., Taylor, P.D., Ilan, M., 2016. Bryozoa from the Mediterraneancoast of Israel. Mediter. Mar. Sci. 17 (2), 440e458. http://dx.doi.org/10.12681/mms.1390.

Sun, Y., Wong, E., Keppel, E., Williamson, J.E., Kupriyanova, E.K., 2017. A global invader or a complex of regionally distributed species? Clarifying the status of an invasive calcareous tubeworm Hydroides dianthus (Verrill, 1873) (Polychaeta: Serpulidae) using DNA barcoding. Mar. Biol. 164 (1), 28. http://dx.doi.org/10. 1007/s00227-016-3058-9.

Tagliapietra, D., Keppel, E., Sigovini, M., Lambert, G., 2012. First record of the colonial ascidian Didemnum vexillum Kott, 2002 in the Mediterranean: lagoon of Venice (Italy). BioInvasions Rec. 1, 247e254. http://dx.doi.org/10.3391/bir.2012. 1.4.02.

Tardent, P., 1959. Capture d'un Abudefduf saxatilis vaigiensis Q. und G. (Pisces, Pomacentridae) dans le Golfe de Naples. Rev. Suisse Zool. 66, 347 e351.

Trainito, E., Doneddu, M., 2014. Nudibranchi del Mediterraneo. $2^{\text {a }}$ edizione, riveduta ed ampliata. Il Castello, Milano, pp. 1 e192.

Traustedt, M.P.A., 1883. Die einfachen Ascidien (Ascidiae simplices) des Golfes von Neapel. Mitt. Zool. Stat. Neapel 4, 448e488.

Tsadok, R., Rubin-Blum, M., Shemesh, E., Tchernov, D., 2015. On the occurrence and identification of Abudefduf saxatilis (Linnaeus, 1758) in the easternmost Mediterranean Sea. Aquat. Invasions 10 (1), 101e105. http://dx.doi.org/10.3391/ai. 2015.10.1.10.

Tsiamis, K., Aydogan, $€$., Bailly, N., Balistreri, P., Bariche, M., Carden-Noad, S., CorsiniFoka, M., Crocetta, F., Davidov, B., Dimitriadis, C., Dragicevic, B., Drakulic, M., Dulcic, J., Escanez, A., Fernandez-Alvarez, F.A., Gerakaris, V., Gerovasileiou, V., Hoffman, R., Izquierdo-Gomez, D., Izquierdo-Munoz, A., Kondylatos, G., Latsoudis, P., Lipej, L., Madiraca, F., Mavric, B., Parasporo, M., Sourbẻs, L., Tasskin, E., Turker, A., Yapici, S., 2015. New Mediterranean biodiversity records (July 2015). Mediterr. Mar. Sci. 16 (2), 472e488. http://dx. doi.org $10.12681 / \mathrm{mms}$. 1440

Tsoi, K.H., Ma, K.Y., Wu, T.H., Fennessy, S.T., Chu, K.H., Chan, T.Y., 2014. Verification of the cryptic species Penaeus pulchricaudatus in the commercially important kuruma shrimp P. japonicus (Decapoda: Penaeidae) using molecular taxonomy. Invertebr. Syst. 28 (5), 476e490. http://dx.doi.org/10.1071/IS14001.

Turk, T., 2000. The opistobranch mollusks (Cephalaspidea, Saccoglossa, Notaspidea, Anaspidea and Nudibranchia) of the Adriatic Sea with special reference to the Slovenian coast. Ann. Ser. Hist. Nat. 10 (2), 161 e172.

Turolla, E., 2006. Considerazioni sul ritrovamento di esemplari adulti di Mercenaria mercenaria (Linnaeus, 1758) in due lagune del Delta del Po. Boll. Malacol. 42, 1 e4.

Turon, X., 1987. Estudio de las ascidias de las costas de Cataluna e Islas Baleares. PhD Thesis. University of Barcelona, Spain.

Turon, X., Tarjuelo, I., Duran, S., Pascual, M., 2003. Characterising invasion processes with genetic data: an Atlantic clade of Clavelina lepadiformis (Ascidiacea) introduced into Mediterranean harbours. Hydrobiologia 503, 29 e35.

Valdes, A., Alexander, J., Crocetta, F., Yokes, M.B., Giacobbe, S., Poursanidis, D., Zenetos, A., Cervera, J.L., Caballer, M., Galil, B.S., Schembri, P.J., 2013. The origin and dispersal pathway of the spotted sea hare Aplysia dactylomela (Mollusca: Opisthobranchia) in the Mediterranean Sea. Aquat. Invasions 8 (4), 427e436. http://dx.doi.org/10.3391/ai.2013.8.4.06

Vella, N., Vella, A., Darmanin, S.A., 2016. The first record of the lowfin chub Kyphosus vaigiensis (Quoy \& Gaimard, 1825) from Malta. J. Black Sea/Mediterr. Environ. 22 (2), $175 e 181$.

Verlaque, M., Rử̇n, S., Mineur, F., Boudouresque, C.F., 2015. 4. Macrophytes. In: Briand, F. (Ed.), CIESM Atlas of Exotic Species in the Mediterranean. CIESM Publishers, Monaco, p. 364

Vidjak, O., Bojanic, N., Gladan, Z.N., Skejic, S., Grbec, B., 2016. First record of small tropical calanoid copepod Parvocalanus crassirostris (Copepoda, Calanoida, Paracalanidae) in the Adriatic Sea. Mediterr. Mar. Sci. 17 (3), 627e633. http://dx doi.org/10.12681/mms.1743.

Wesenberg-Lund, E., 1957. Sipunculoidea from the coast of Israel. Bull. Res. Counc. Isr. Sect. B Zool. 6, 193e200.

WoRMS Editorial Board, 2016. World Register of Marine Species. http://www. marinespecies.org (Last Accessed in December 2016).

Yokeș, B.M., Dalyan, C., Karhan, S.Ü., Demir, V., Tural, U., Kalkan, E., 2012. Alien Opisthobranchs from Turkish coasts: first record of Plocamopherus tilesii Bergh, 1877 from the Mediterranean. Triton 25 (Suppl. 1), 1e9.

Zaouali, J., Ben Souissi, J., Stohr, S., D'Udekem D'Acoz, C., Ben Abdallah, A., 2007. Contribution ả l'etudes peuplements actuels des substrats solides de l'etage mediolittoral de la Mediterranee meridionale. Rapp. Comm. Int. Mer. Medit 38, 639.

Zenetos, A., Arianoutsou, M., Bazos, I., Balopoulou, S., Corsini-Foka, M., Dimiza, M., Drakopoulou, P., Katsanevakis, S., Kondylatos, G., Koutsikos, N., Kytinou, E. Lefkaditou, E., Pancucci-Papadopoulou, M.A., Salomidi, M., Simboura, N., Skoufas, G., Trachalakis, P., Triantaphyllou, M., Tsiamis, K., Xentidis, N.J., Poursanidis, D., 2015. ELNAIS: A collaborative network on Aquatic NIS in Greece. Manag. Biol. Invasion 6 (2), 185e196. http://dx.doi.org/10.3391/mbi.2015.6.2.09.

Zenetos, A., Çinar, M.E., Pancucci-Papadopoulou, M.A., Harmelin, J.G., Furnari, G., Andaloro, F., Bellou, N., Streftaris, N., Zibrowius, H., 2005. Annotated list of alien marine species in the Mediterranean with emphasis on worst invasive species. Mediterr. Mar. Sci. 6 (2), 63e118. http://dx.doi.org/10.12681/mms.186.

Zenetos, A., Gofas, S., Verlaque, M., Cinar, M.E., García Raso, J.E., Bianchi, C.N., Morri, C., Azzurro, E., Bilecenoglu, M., Froglia, C., Siokou, I., Violanti, D., Sfriso, A., 
San Martín, G., Giangrande, A., Katagan, T., Ballesteros, E., Ramos-Espla, A., Mastrototaro, F., Ocan a, O., Zingone, A., Gambi, M.C., Streftaris, N., 2011a. Errata to the Review Article (Medit. Mar. Sci. 11/2, 2010, 381e493): "Alien species in the Mediterranean Sea by 2010. A contribution to the application of European Union's Marine Strategy Framework Directive (MSFD). Part I. Spatial distribution”. Mediterr. Mar. Sci. 12 (2), 509e514. http://dx.doi.org/10.12681/mms.49.

Zenetos, A., Gofas, S., Morri, C., Rosso, A., Violanti, D., García Raso, J.E., Çinar, M.E., Almogi-Labin, A., Ates, A.S., Azzurro, E., Ballesteros, E., Bianchi, C.N., Bilecenoglu, M., Gambi, M.C., Giangrande, A., Gravili, C., Hyams-Kaphzan, O., Karachle, P.K., Katsanevakis, S., Lipej, L., Mastrototaro, F., Mineur, F., PancucciPapadopoulou, M.A., Ramos-Espla, A., Salas, C., San Martín, G., Sfriso, A., Streftaris, N., Verlaque, M., 2012. Alien species in the Mediterranean Sea by 2012. A contribution to the application of European Union's Marine strategy framework directive (MSFD). Part 2. Introduction trends and pathways. Mediterr. Mar. Sci. 13 (2), 328e352. http://dx.doi.org/10.12681/mms.327.

Zenetos, A., Gofas, S., Russo, G., Templado, J., 2004. CIESM Atlas of Exotic Species in the Mediterranean. Molluscs, vol. 3. CIESM Publishers, Monaco, p. 376.

Zenetos, A., Gofas, S., Verlaque, M., Çinar, M.E., García Raso, J.E., Bianchi, C.N., Morri, C., Azzurro, E., Bilecenoglu, M., Froglia, C., Siokou, I., Violanti, D., Sfriso, A., San Martín, G., Giangrande, A., Katałan, T., Ballesteros, E., Ramos-Espla, A., Mastrototaro, F., Ocarna, O., Zingone, A., Gambi, M.C., Streftaris, N., 2010. Alien species in the Mediterranean Sea by 2010. A contribution to the application of European Union's Marine strategy framework directive (MSFD). Part I. Spatial distribution. Mediterr. Mar. Sci. 11 (2), 381e493. http://dx.doi.org/10.12681/ mms. 87 .

Zenetos, A., Katsanevakis, S., Poursanidis, D., Crocetta, F., Damalas, D., Apostolopoulos, G., Gravili, C., Vardala-Theodorou, E., Malaquias, M., 2011b. Marine alien species in Greek Seas: additions and amendments by 2010 . Mediterr. Mar. Sci. 12 (1), 95e120. http://dx.doi.org/10.12681/mms.55.

Zenetos, A., Meriç, E., Verlaque, M., Galli, P., Boudouresque, C.-F., Giangrande, A., Cinar, M.E., Bilecenoylu, M., 2008. Additions to the annotated list of marine alien biota in the Mediterranean with special emphasis on Foraminifera and Parasites. Mediterr. Mar. Sci. 9 (1), 119e165. http://dx.doi.org/10.12681/mms. 146.

Zenetos, A., Pancucci-Papadopoulou, M.-A., Zogaris, S., Papastergiadou, E. Vardakas, L., Aligizaki, K., Economou, A.N., 2009. Aquatic alien species in Greece (2009): tracking sources, patterns and effects on the ecosystem. J. Biol. Res. (Thessalon.) 12 (1), 135e172

Zhan, A., MacIsaac, H.J., Cristescu, M.E., 2010. Invasion genetics of the Ciona intestinalis species complex: from regional endemism to global homogeneity. Mol. Ecol. 19, 4678e4694. http://dx.doi.org/10.1111/j.1365-294X.2010.04837.x.

Zibrowius, H., 1974. Oculina patagonica, Scleractiniaire hermatypique introduit en Mediterranee. Helgol. Wiss. Meer. 26, 153 e173.

Zibrowius, H., Bitar, G., 2003. Invertebres marins exotiques sur la cAte du Liban. Leban. Sci. J. 4, 67e74.

\section{Websites}

AquaNIS: Information System on Aquatic Non-Indigenous and Cryptogenic Species (http://www.corpi.ku.lt/databases/index.php/aquanis).

CIESM: CIESM Atlas of Exotic Species in the Mediterranean (http://www.ciesm.org/ online/atlas/index.html).

DAISIE: Delivering Alien Invasive Species Inventories for Europe (http://www. europe-aliens.org)

EASIN: European Alien Species Information Network (https://easin.jrc.ec.europa.eu/

MAMIAS: Marine Mediterranean Invasive Alien Species Database: accessible via EASIN

NoBANIS: The European Network on Invasive Alien Species (https://www.nobanis. org). 